US Army Corps

of Engineers ${ }_{\circledast}$

Engineer Research and

Development Center

\title{
Laboratory Tensile Performance of Joint Adhesive for Asphalt Pavements
}

W. Jeremy Robinson, Jesse D. Doyle, and James A. Harrison

April 2019

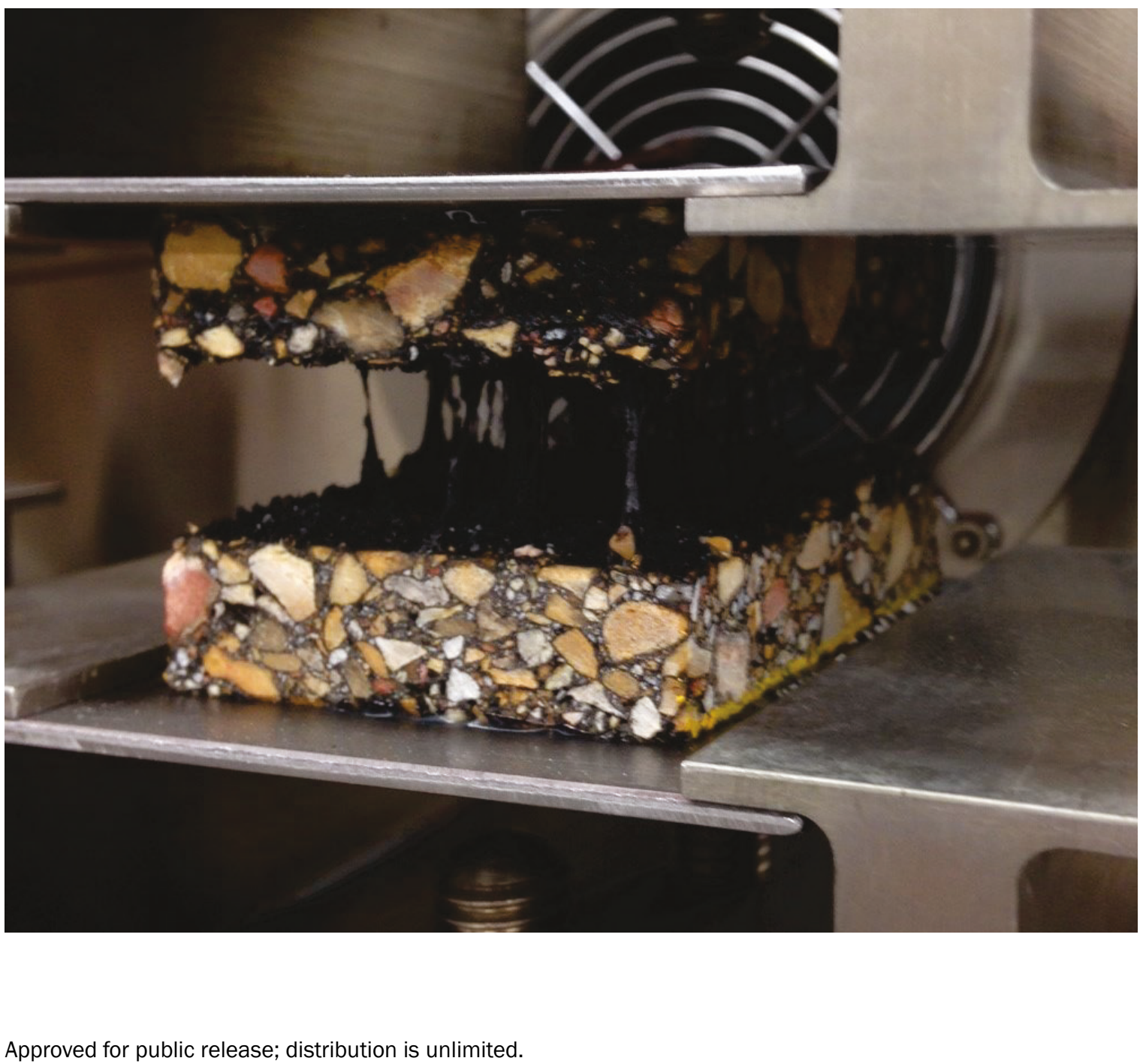


The U.S. Army Engineer Research and Development Center (ERDC) solves the nation's toughest engineering and environmental challenges. ERDC develops innovative solutions in civil and military engineering, geospatial sciences, water resources, and environmental sciences for the Army, the Department of Defense, civilian agencies, and our nation's public good. Find out more at www.erdc.usace.army.mil.

To search for other technical reports published by ERDC, visit the ERDC online library at http://acwc.sdp.sirsi.net/client/default. 


\title{
Laboratory Tensile Performance of Joint Adhesive for Asphalt Pavements
}

\author{
W. Jeremy Robinson, Jesse D. Doyle, and James A. Harrison \\ Geotechnical and Structures Laboratory \\ U.S. Army Engineer Research and Development Center \\ 3909 Halls Ferry Road \\ Vicksburg, MS 39180-6199
}

Final report

Approved for public release; distribution is unlimited.

\author{
Prepared for U.S. Army Installation Management Command \\ 2405 Gun Shed Road \\ Fort Sam Houston, TX 78234-1223 \\ Under Work Unit 464296
}




\section{Abstract}

Deterioration of asphalt pavement joints is one of the most commonly observed distresses on Army airfield pavements. Joint opening or cracking is typically caused by temperature cycling and associated thermal expansion of the asphalt pavements and is often seen around the perimeter of hot mix asphalt patching and along longitudinal paving joints. An improvement in joint performance has the potential for significant maintenance cost savings to the Army. The objective of this effort was to perform a literature review of current specifications and available field evaluation studies and to conduct laboratory testing of currently available joint adhesive products to observe tensile strength and elongation characteristics at a variety of test temperatures. Review of limited highway evaluations indicate that, based on visual inspection, joint adhesives have shown improvement in long-term performance; and laboratory results suggest that, based on observed elongation, joint adhesives can provide an improvement in asphalt joint behavior.

DISCLAIMER: The contents of this report are not to be used for advertising, publication, or promotional purposes. Citation of trade names does not constitute an official endorsement or approval of the use of such commercial products. All product names and trademarks cited are the property of their respective owners. The findings of this report are not to be construed as an official Department of the Army position unless so designated by other authorized documents. 


\section{Contents}

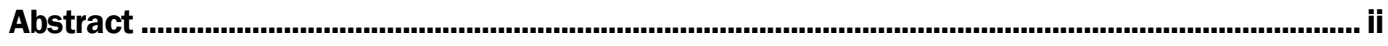

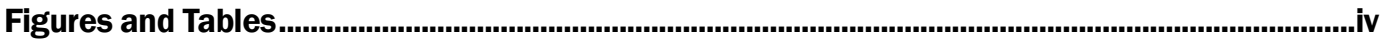

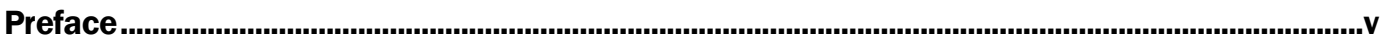

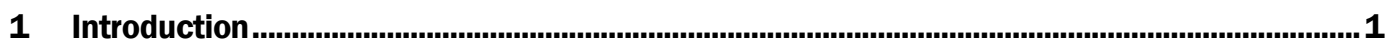

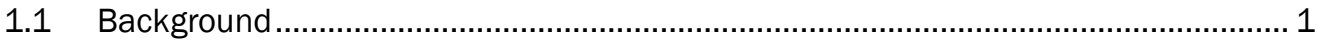

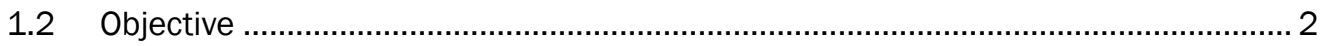

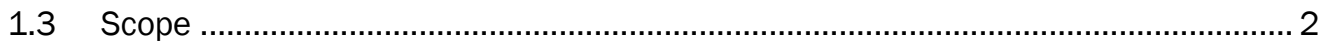

2 Review of Current Specifications and Relevant Research ........................................................4

2.1 Current airfield specifications......................................................................... 4

2.2 Relevant longitudinal joint research ................................................................... 6

2.3 Summary of literature review.................................................................................. 10

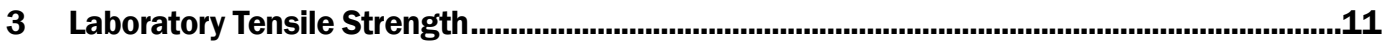

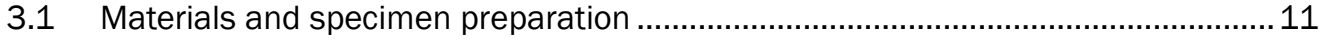

3.2 Tensile test equipment ................................................................................ 15

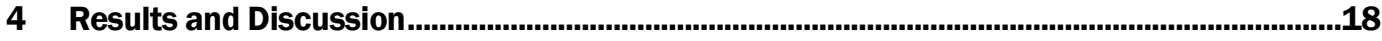

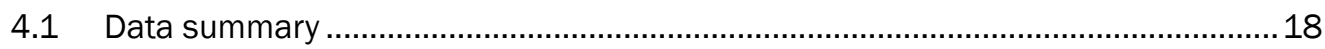

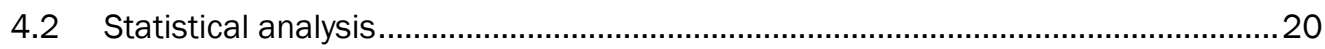

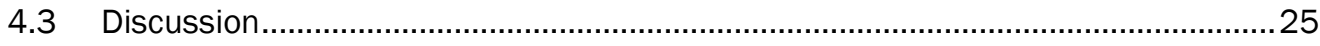

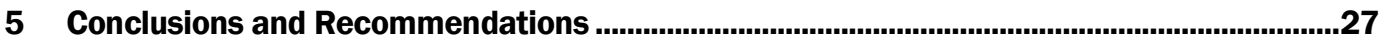

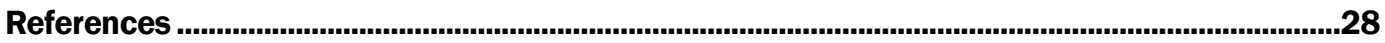

Appendix A: Laboratory Test Data ............................................................................................30

Report Documentation Page 


\section{Figures and Tables}

\section{Figures}

Figure 1. Cracking around HMA patch. .....................................................................................

Figure 2. Longitudinal paving joint deterioration. ............................................................................ 2

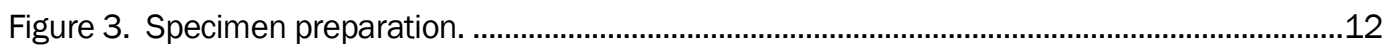

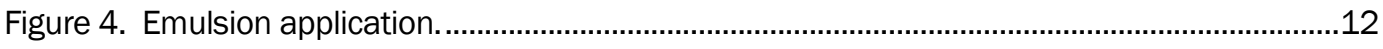

Figure 5. Joint adhesive preparation. .............................................................................................

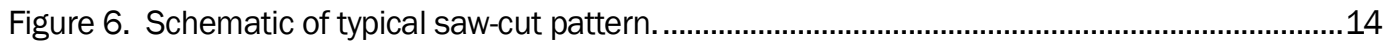

Figure 7. Beam specimen preparation......................................................................................14

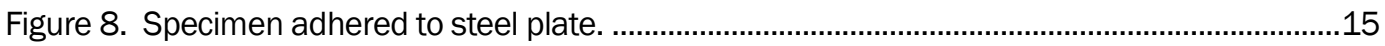

Figure 9. ATS load frame and environmental chamber. .................................................................16

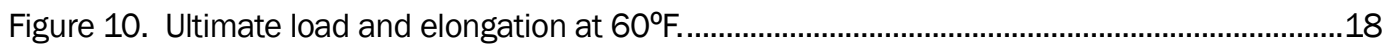

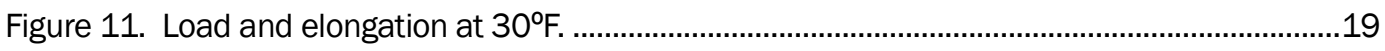

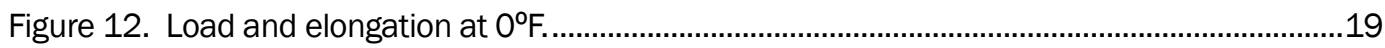

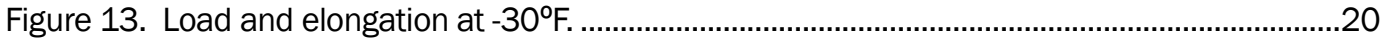

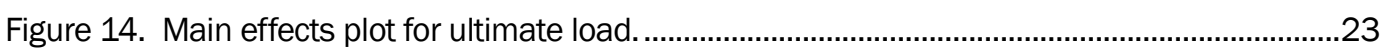

Figure 15. Interaction plot for ultimate load. ............................................................................2

Figure 16. Elongation during joint adhesive (Crafco $\AA)$ test. ............................................................25

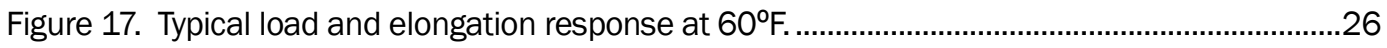

\section{Tables}

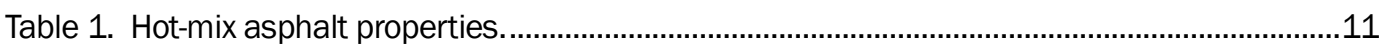

Table 2. Laboratory test temperature matrix.............................................................................16

Table 3. Statistical summary for ultimate elongation (all treatments).............................................20

Table 4. Multiple pairwise comparison for ultimate elongation (all treatments)..............................21

Table 5. Statistical summary for ultimate load (all treatments).......................................................21

Table 6. Multiple pairwise comparison for test temperature (all treatments). .................................21

Table 7. Multiple pairwise comparison for treatment (all treatments)...............................................22

Table 8. Statistical ANOVA summary for ultimate load (jointed specimens only).............................22

Table 9. Multiple comparison procedure results (jointed specimens only).......................................2 


\section{Preface}

This study was conducted for the U.S. Army Installation Management Command at Fort Sam Houston, TX.

The work was performed by the Airfields and Pavements Branch (GMA) of the Engineering Systems Division (GM), U.S. Army Engineer Research and Development Center, Geotechnical and Structures Laboratory (ERDCGSL). At the time of publication, Dr. Timothy W. Rushing was Chief, CEERD-GMA; Mr. Jeffrey G. Averett was Acting Chief, CEERD-GM; and Ms. Pamela G. Kinnebrew, CEERD-GZ-T, was the Technical Director for Military Engineering. The Deputy Director of ERDC-GSL was Mr. Charles W. Ertle II, and the Director was Mr. Bartley P. Durst.

COL Ivan P. Beckman was the Commander of ERDC, and Dr. David W. Pittman was the Director. 


\section{Unit Conversion Factors}

\begin{tabular}{|c|c|c|}
\hline Multiply & By & To Obtain \\
\hline cubic feet & 0.02831685 & cubic meters \\
\hline cubic inches & $1.6387064 \mathrm{E}-05$ & cubic meters \\
\hline cubic yards & 0.7645549 & cubic meters \\
\hline degrees Fahrenheit & $(F-32) / 1.8$ & degrees Celsius \\
\hline feet & 0.3048 & meters \\
\hline gallons (U.S. liquid) & $3.785412 \mathrm{E}-03$ & cubic meters \\
\hline inches & 0.0254 & meters \\
\hline inch-pounds (force) & 0.1129848 & newton meters \\
\hline microinches & 0.0254 & micrometers \\
\hline ounces (mass) & 0.02834952 & kilograms \\
\hline ounces (U.S. fluid) & $2.957353 \mathrm{E}-05$ & cubic meters \\
\hline pints (U.S. liquid) & 4.73176 E-04 & cubic meters \\
\hline pints (U.S. liquid) & 0.473176 & liters \\
\hline pounds (force) & 4.448222 & newtons \\
\hline pounds (force) per square foot & 47.88026 & pascals \\
\hline pounds (force) per square inch & 6.894757 & kilopascals \\
\hline pounds (mass) & 0.45359237 & kilograms \\
\hline pounds (mass) per cubic foot & 16.01846 & kilograms per cubic meter \\
\hline pounds (mass) per cubic inch & $2.757990 \mathrm{E}+04$ & kilograms per cubic meter \\
\hline pounds (mass) per square foot & 4.882428 & kilograms per square meter \\
\hline pounds (mass) per square yard & 0.542492 & kilograms per square meter \\
\hline quarts (U.S. liquid) & $9.463529 \mathrm{E}-04$ & cubic meters \\
\hline square feet & 0.09290304 & square meters \\
\hline square inches & 6.4516 E-04 & square meters \\
\hline square yards & 0.8361274 & square meters \\
\hline yards & 0.9144 & meters \\
\hline
\end{tabular}




\section{Introduction}

\subsection{Background}

Deterioration of asphalt pavement joints is one of the most commonly observed distresses on Army airfield pavements. Joint opening or cracking is typically caused by low density, temperature cycling, and associated thermal expansion and contraction of the asphalt pavements and is often seen around the perimeter of hot mix asphalt (HMA) patching (Figure 1) and along longitudinal paving joints (Figure 2). The intrusion of water and air can lead to accelerated oxidation and weathering of the area in and around the crack and can increase the potential for further deterioration and the probability of foreign object debris (FOD). An improvement in joint performance has the potential to increase HMA pavement life and significantly reduce maintenance costs to the Army.

Figure 1. Cracking around HMA patch.

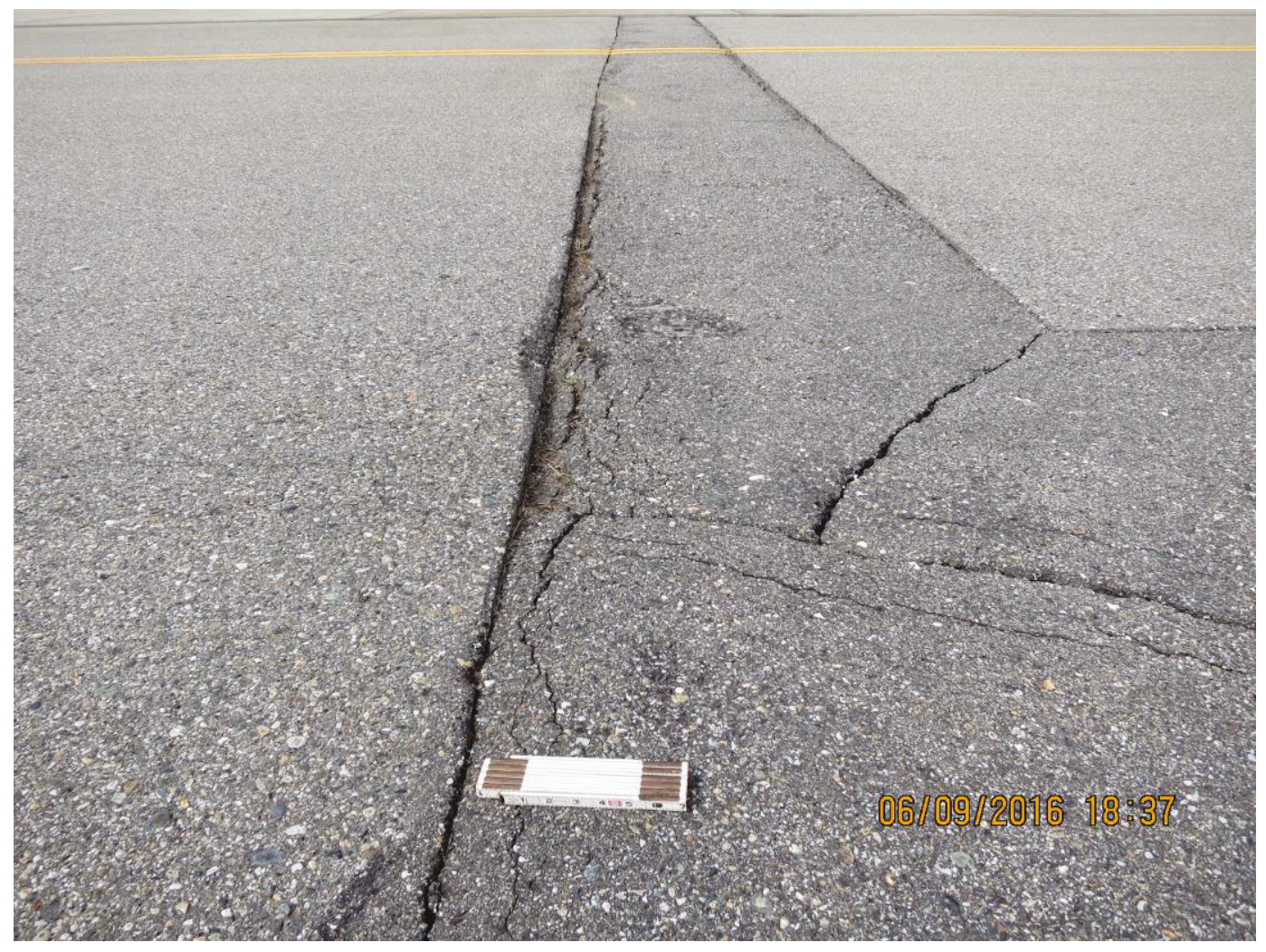


Figure 2. Longitudinal paving joint deterioration.

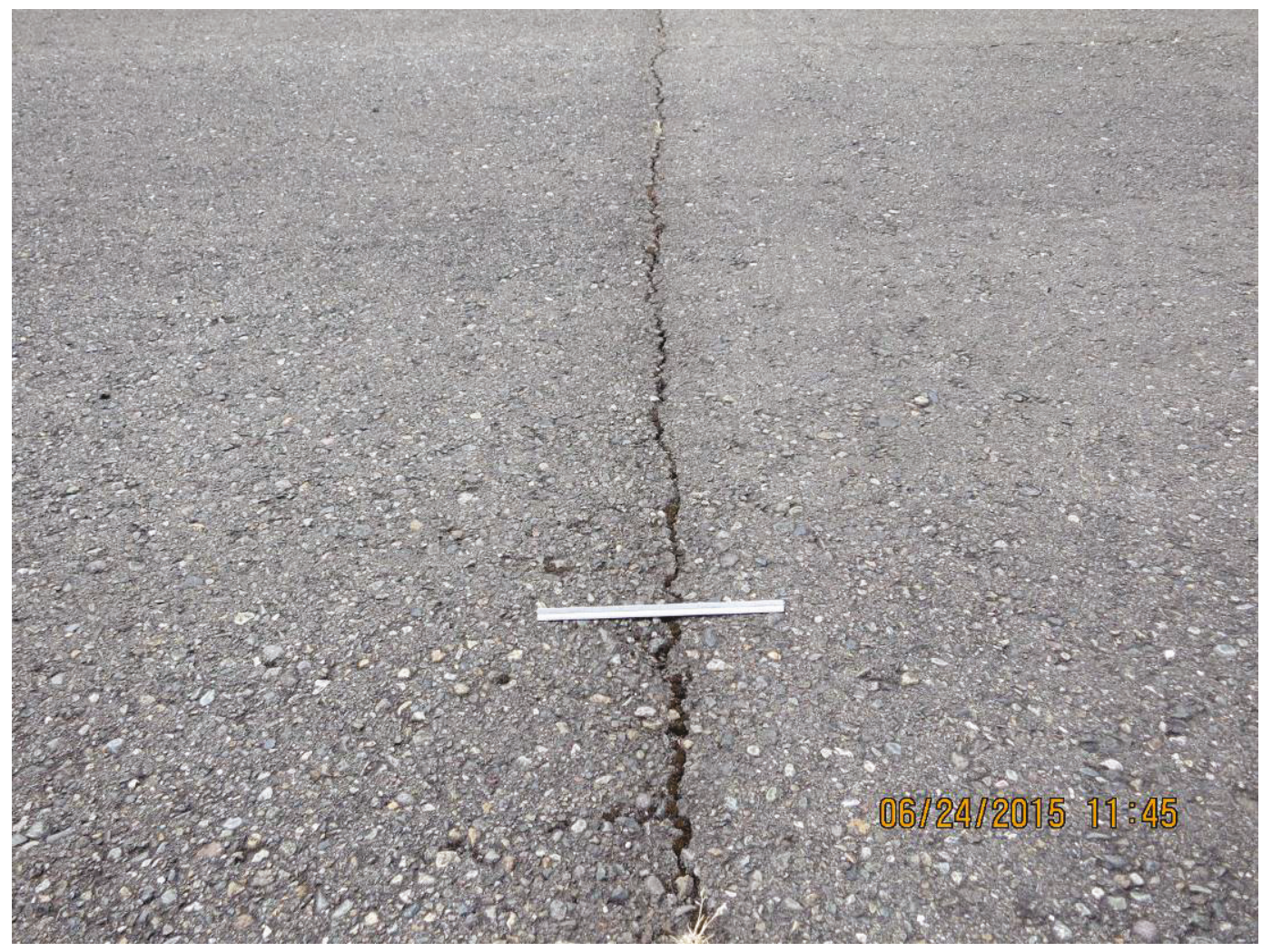

\subsection{Objective}

The technical objective of this effort was to conduct laboratory testing of currently available joint adhesive products. These different products were compared to one another as well as to specimens treated with a standard emulsion and to untreated specimens. Performance was measured by means of tensile strength tests performed in the U.S. Army Engineer Research and Development Center (ERDC) Joint Sealant Research Laboratory. Results were evaluated and recommendations made to the potential benefit of joint adhesive application on asphalt paving joints.

\subsection{Scope}

The scope of this project included a literature review of current specifications related to longitudinal joint construction on airfield pavements and a review of available field evaluation studies to determine field performance characteristics of asphalt joint adhesive products. An overview of practices related to asphalt joint construction -- including, but not limited to, wedge joints, joint heaters, cut back joints, joint adhesives, and joint sealers -- is provided. 
A laboratory study was performed to determine tensile behavior of joints prepared using joint adhesives, typical emulsified tack coat (standard tack coat), no adhesive (only cold/hot adhesion), and no joint (solid HMA). Test specimens were fabricated using a Superpave gyratory compactor, and beam specimens were saw-cut from the composite Superpave gyratory specimens to perform tensile strength testing. Specimens were placed in an Applied Test Systems (ATS) testing frame for direct tensile strength determination, and a temperature sweep was performed to assemble strength data over a range of climatic conditions. Specimens were tested until failure, and the mode of failure (joint failure at the interface or tensile failure of the asphalt mixture) was noted. Data obtained from tensile strength determinations are presented, and recommendations are made regarding the laboratory performance of various joint treatment options. 


\section{Review of Current Specifications and Relevant Research}

\subsection{Current airfield specifications}

Federal Aviation Administration (FAA) and Department of Defense (DOD) guide specifications were reviewed to determine current asphalt joint construction practices for airfield pavements.

For FAA-funded projects, Airport Construction Standards (AC 150/537010) Item P-401, Hot Mix Asphalt (HMA) Pavements (2014) provides guidance for construction of longitudinal joints. Below is an excerpt from Subsection 401-4.13, Joints regarding longitudinal joint construction:

Longitudinal joints which have been left exposed for more than four (4) hours; the surface temperature has cooled to less than $175^{\circ} \mathrm{F}\left(80^{\circ} \mathrm{C}\right)$; or are irregular, damaged, uncompacted or otherwise defective shall be cut back 3 in. $(75 \mathrm{~mm})$ to 6 in. (150 $\mathrm{mm}$ ) to expose a clean, sound, uniform vertical surface for the full depth of the course. All cutback material shall be removed from the project. Asphalt tack coat or other product approved by the Engineer shall be applied to the clean, dry joint, prior to placing any additional fresh HMA against the joint. Any laitance produced from cutting joints shall be removed by vacuuming and washing.

Further, it is noted that the Contractor is allowed to use joint heaters to provide additional joint density quality control. The use of joint heaters is not required and can be used at the Contractor's expense. Acceptance is based on cores taken for the measurement of joint density.

Language regarding joint construction is contained in DOD specification Division 32 Section 32-12-15.13 Hot-Mix Asphalt Airfield Paving (November 2015) as follows:

Cut back longitudinal joints which are irregular, damaged, uncompacted, cold (less than $80 \operatorname{deg} \mathrm{C}(175 \operatorname{deg} \mathrm{F})$ at the time of placing the adjacent lane), or otherwise defective, a maximum of $75 \mathrm{~mm}$ ( 3 in.) from the top edge of the lift with a cutting wheel to expose a clean, sound, near vertical 
surface for the full depth of the course. Remove all cutback material from the project. Cutting equipment that uses water as a cooling or cutting agent nor milling equipment is permitted. Provide a light tack coat of asphalt material to all contact surfaces prior to placing any fresh mixture against the joint.

Joint acceptance is based on cores centered on the joint. Review of FAA specifications indicate that joint density greater than $93.3 \%$ of laboratory compacted specimens is acceptable. When acceptance values are calculated based on theoretical maximum density (TMD), which gives an indication of in-place air voids, it is found that joint densities can range from 88.6 to $91.4 \%$ (11.4 to $8.6 \%$ in-place air voids). DOD specifications require average joint density to range from 90.5 to $92.5 \%$ based on TMD ( 9.5 to $7.5 \%$ in-place air voids).

Research by Mallick et al. (2003) and Cooley et al. (2001 and 2002) conducted to measure field permeability in highway pavements has shown that, at densities less than approximately 93\% (based on TMD), pavements become excessively permeable. Further, Cooley et al. (2001) concluded that, as nominal maximum aggregate size (NMAS) increases, required density to mitigate excessive permeability increases. In-place density of at least $92.3 \%$ of TMD (7.7\% air voids or less) is required to minimize permeability of 9.5-mm and 12.5-mm NMAS mixtures. For 19.0-mm NMAS mixtures, in-place density of at least $94.5 \%$ of TMD (5.5\% air voids or less) is required to minimize permeability (Cooley et al. 2001).

Linden et al. (1989) looked at the importance of compaction on asphalt pavement service life based on a literature review, a survey of state highway agencies, and Washington state pavement management data. Their research indicated that pavement service life was reduced by only $2 \%$ to $10 \%$ for in-place density of $92 \%$ of TMD ( $8 \%$ air voids). For in-place density of $91 \%$ of TMD ( $9 \%$ air voids), pavement service life was reduced by $6 \%$ to $21 \%$. When in-place density reached $90 \%$ of TMD (10\% air voids), service life was reduced by $17 \%$ to $30 \%$. Finally, when in-place density was only $88 \%$ of TMD ( $12 \%$ air voids), service life was significantly reduced by $36 \%$ to $50 \%$. 


\subsection{Relevant longitudinal joint research}

Kandhal and Rao (1994) document a field study of longitudinal joint construction techniques on an interstate pavement in Michigan (7 techniques) and a secondary state route in Wisconsin (8 techniques). Joint density achieved during construction was measured, and the performance of these field projects was evaluated after one winter season. The cutting-wheel technique (such as is specified for airfield paving) consistently had the best appearance after one winter and was among the highest joint densities measured.

Kandhal and Mallick (1996) document a field study of longitudinal joint construction techniques on interstate pavements in Colorado (seven techniques) and Pennsylvania (two techniques). Joint density achieved during construction was measured, and the performance of these field projects was evaluated after one winter season. A general observation was that the initial performance of the joints was influenced by overall density of the joint, with higher joint density having better performance than lower joint density.

Kandhal et al. (2002) evaluated eight different longitudinal joint construction techniques on a two-lane state route in Lancaster County, PA. The techniques included

- Joint maker - automated joint construction device that attaches to the side of the screed. The device forces extra material at the joint and claims to ensure high density and better aggregate interlock at the joint.

- Rolling from hot side - compaction of the joint was achieved by rolling with a majority of the drum on the hot side of the lane and an approximate 6-in. drum overlap on the cold side.

- Rolling from cold side - compaction of the joint was achieved by rolling with a majority of the drum on the cold side of the lane and an approximate 6-in. drum overlap on the hot side.

- Rolling from hot side 6 in. away from joint - compaction of the joint was achieved by making the first roller pass 6 in. away from the joint on the hot side and the second pass on the joint with an approximate 6-in. overlap on the cold side.

- Cutting wheel -- involves cutting back a portion of the existing cold joint and discarding the low density edge material. 
- Edge-restraining device - device that attaches to the roller and provides confinement to the unsupported edge.

- Rubberized asphalt tack coat (joint adhesive) - rubberized asphalt tack coat (Crafco ${ }^{\circledR}$ pavement joint adhesive No. 34524) applied to the face of the unconfined edge.

- New Jersey wedge - wedge joint consisting of a 3:1 taper formed during construction by using a sloping steel plate attached to the paver screed extension.

Cores were taken from each section both at the joint and 12 in. away from the joint immediately after construction. The edge-restraining device and cutting-wheel techniques yielded the best density immediately after construction. Also, a team of engineers visually inspected and rated each joint in terms of cracking and raveling over a 6-year period postconstruction.

It was found that the test section with rubberized asphalt tack coat performed the best with no joint cracking after 6 years, while having the second lowest joint density (87.1\% of TMD) immediately following construction. The joint made with the cutting wheel was found to perform second best, but it was noted that the quality of the cut joint depended on the skill of the operator in making the cut and the paver operator in matching the cut edge. Rolling from the hot side 6 in. from the joint was found to be the third best performer, followed by the New Jersey wedge. After rubberized tack coat, the next three performing joint types all had cracking in less than $10 \%$ of the joint length evaluated. The edgerestraining device was an intermediate performing technique with cracking in $35 \%$ of the joint length evaluated. Finally, the joint maker, rolling from hot side, and rolling from cold side were all poor performing techniques with cracking in $85-99 \%$ of the joint length evaluated.

Based on the 6-year field performance of the Pennsylvania project and observations made from the Michigan, Wisconsin, and Colorado projects, general recommendations were made for longitudinal joint construction by Kandhal et al. (2002). Specifically, they recommended that rubberized joint adhesive or a notched-wedge joint be used. A rolling technique commencing from the hot side 6 in. away from the joint was the recommended construction method. 
Williams (2011) evaluated eight longitudinal joint construction techniques on a 5 -lane highway section and a 3-lane highway section in Arkansas. The techniques evaluated included

- Joint adhesive - Crafco ${ }^{\circledR}$ pavement joint adhesive.

- Joint heater - infrared joint heater used to raise the surface temperature of the cold lane to a range of $212^{\circ} \mathrm{F}$ to $250^{\circ} \mathrm{F}$.

- Notched wedge - device that attaches to the paver screed extension to form a 1/2-in. notch and a 1:12 wedge.

- Joint stabilizer - post-applied polymerized maltene-based emulsion product designed to penetrate the pavement surface and affect the chemistry of the in-place asphalt binder.

- Tack coat - standard tack coat (SS-1) applied to the cold joint face.

- Rolling from hot side - compaction of the joint was achieved by rolling with a majority of the drum on the hot side of the lane and an approximate 6-in. drum overlap on the cold side.

- Rolling from hot side 6 in. away from joint - compaction of the joint was achieved by making the first roller pass 6 in. away from the joint on the hot side and the second pass on the joint with an approximate 6-in. overlap on the cold side.

- Rolling from cold side - compaction of the joint was achieved by rolling with a majority of the drum on the cold side of the lane and an approximate 6-in. to 12-in. drum overlap on the hot side.

Each technique was evaluated based on density, absorption, permeability, and infiltration. It was found that, in general, the joint heater, joint stabilizer, and notched-wedge techniques demonstrated superior performance based on the measured values. Traditional rolling and joint adhesives were not successful in producing similar quality based on the measured values. It was stated that good construction practices may be sufficient to produce quality joints, and no specific recommendation was made to suggest a particular construction technique for longitudinal joints.

Morgan (2009) studied the effect of using joint adhesive products on the performance of longitudinal paving joints in New York. Seven overlay pavement projects were selected for this field study. Joint adhesives from three different manufacturers were evaluated. For six of the projects, the standard practice (in New York) wedge joint was used in combination with joint adhesive manufactured by either $\mathrm{Crafco}^{\circledR}$ or Deery ${ }^{\circledR}$ (note that the Deery ${ }^{\circledR}$ product now appears to be owned or manufactured by $\mathrm{Crafco}^{\circledR}$ ). 
For the seventh project, a butt joint in combination with a product from Asphalt Materials Inc. was used. Field evaluations of the test sections were performed annually for 3 or 4 years prior to the report. The overall conclusion was that the joint adhesive sections were performing as well as or better than the control sections in terms of cracking.

Huang et al. (2010) evaluated joint adhesives, joint sealers, and an infrared heater as a means of improving longitudinal joint performance on a 2-lane state route in Tennessee. Compaction procedures were the same for each section to eliminate the effect of different compaction methods. Core samples were obtained and tested for total air voids, permeability, and indirect tensile (IDT) strength. It was found that the longitudinal joint constructed without any special joint treatment had the highest air void content and permeability and the lowest IDT strength. Joints constructed with an infrared heater were found to be the best performer, having lower air voids and permeability and increased IDT strength. A slight reduction in air void content and IDT strength and a more significant permeability reduction was observed in joints treated with a joint adhesive.

Mallick et al. (2007) performed an extensive literature review including Kandhal and Rao (1994), Kandhal and Mallick (1996), and Kandhal et al. (2002) (all reviewed previously in this report) on construction of longitudinal asphalt joints to develop technical guidance for the FAA. The report consisted of a review of available research reports related to longitudinal joint construction (it is noted that most research identified was focused on highway pavements), summary of experience of airfield engineers, and evaluation of FAA and DOD specifications for airfields. The information was combined and the following best practices were recommended in decreasing order of preference:

- Echelon paving - operating two or more pavers side-by-side to eliminate a cold joint.

- Combination of notched-wedge joint and rubberized asphalt tack coat - a notched-wedge joint is constructed with a 1/2-in. notch and a 1:12 taper. The notch and taper are coated with joint adhesive prior to placement of the overlap wedge.

- Rubberized asphalt tack coat (joint adhesive) - rubberized joint adhesive is applied on the face of the cold lane. 
- Notched-wedge joint - similar to notched wedge with adhesive except that a conventional tack coat is used.

- Cutting wheel -- involves cutting back a portion of the existing cold joint and discarding the low density edge material.

For all the methods described (with the exception of echelon paving), a minimum joint density of $90.5 \%$ of TMD is recommended based on measurements made on a 6-in.-diameter core.

\subsection{Summary of literature review}

A review of current airfield specifications indicates that cutting back cold joints and applying a light tack coat is the current state of practice. It is noted that an application rate for tacking the joint is not defined, suggesting that acceptable application is determined by the Contractor or project inspection personnel. Joint heaters are allowed (but not required) in FAA specifications.

Review of literature indicates that little work has been performed to evaluate longitudinal joint construction techniques for airfield pavements and that most work has been performed for highway pavements. Since joint deterioration is a non-load associated distress, findings from highway pavement research should be generally applicable to airfield pavements. A number of joint compaction techniques, joint construction techniques, and joint treatments have been evaluated in an attempt to improve long-term performance and durability. Various techniques have been found to improve longitudinal joint construction and performance; however, the literature suggests that a single technique has not been shown to be the best treatment in all cases.

In terms of initial performance, it appears that echelon paving or reheating the cold side with infrared heaters improves initial air void content, permeability, and indirect tensile strength of the longitudinal joint.

In terms of long-term performance, the literature suggests that echelon paving, wedge joints with/without joint adhesive, and joint adhesive alone provide improved long-term performance. Cutting back the cold joint was found to improve long-term performance, but it is noted that the skill of the operator could impact the quality of this technique. 


\section{Laboratory Tensile Strength}

\subsection{Materials and specimen preparation}

Laboratory test specimens were fabricated using a Superpave gyratory compactor set to 85 gyrations. A locally available asphalt mixture (Table 1) was used to compact specimens approximately $150 \mathrm{~mm}$ in diameter and approximately $115 \mathrm{~mm}$ in height. A density of 96\% of TMD (or 4\% laboratory air voids as determined by AASHTO T166 (2013) and AASHTO T209 (2012) was targeted to match mix design compaction procedures. Specimens were saw-cut mid-depth using a diamond-tipped laboratory saw (Figure 3) to expose a cut face similar to field construction techniques.

A CSS-1 emulsion was used for the standard tack coat and was obtained locally from Ergon Inc., Vicksburg, MS. Pavon provided the polymer modified emulsion, and $\mathrm{Crafco}^{\circledR}$ Inc. provided the rubberized joint adhesive.

Table 1. Hot-mix asphalt properties.

\begin{tabular}{|c|c|c|}
\hline \multicolumn{2}{|l|}{ Test Property } & Result \\
\hline \multicolumn{2}{|c|}{$N_{\text {design }}$} & 85 \\
\hline \multicolumn{2}{|c|}{ Binder Grade } & PG 67-22 \\
\hline \multicolumn{2}{|c|}{ Compaction Temp ( $\left.{ }^{\circ} \mathrm{F}\right)$} & 300 \\
\hline \multirow{9}{*}{ 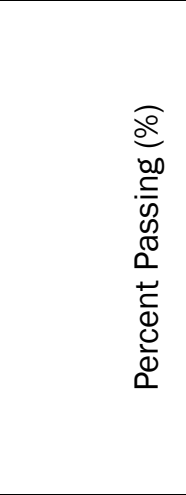 } & $1.0 \mathrm{in} .(25.0 \mathrm{~mm})$ & 100 \\
\hline & $3 / 4$ in. $(19.0 \mathrm{~mm})$ & 100 \\
\hline & $1 / 2$ in. $(12.5 \mathrm{~mm})$ & 95 \\
\hline & $3 / 8$ in. $(9.5 \mathrm{~mm})$ & 87 \\
\hline & $\# 4(4.75 \mathrm{~mm})$ & 57 \\
\hline & \#8 (2.36 mm) & 37 \\
\hline & $\# 30(0.60 \mathrm{~mm})$ & 19 \\
\hline & $\# 50(0.30 \mathrm{~mm})$ & 12 \\
\hline & \#200 (0.075 mm) & 5.3 \\
\hline \multicolumn{2}{|l|}{ RAP (\%) } & 11 \\
\hline \multicolumn{2}{|l|}{ RAP AC (\%) } & 5.6 \\
\hline \multicolumn{2}{|l|}{$\mathrm{G}_{\mathrm{sb}}$} & 2.520 \\
\hline \multicolumn{2}{|l|}{$\mathrm{Pb}(\%)$} & 5.4 \\
\hline \multicolumn{2}{|l|}{$\mathrm{Pbe}_{\mathrm{be}}(\%)$} & 4.8 \\
\hline \multicolumn{2}{|l|}{$\mathrm{Gmm}_{\mathrm{mm}}$} & 2.366 \\
\hline \multicolumn{2}{|l|}{ VMA (\%) } & 14.1 \\
\hline
\end{tabular}


Figure 3. Specimen preparation.

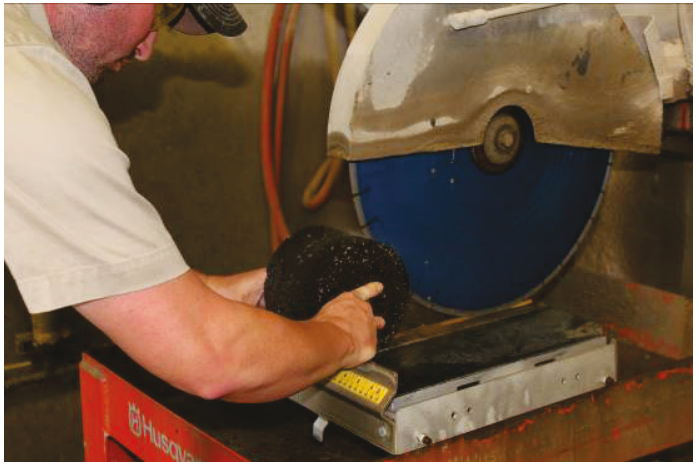

(a) Diamond-tipped saw.

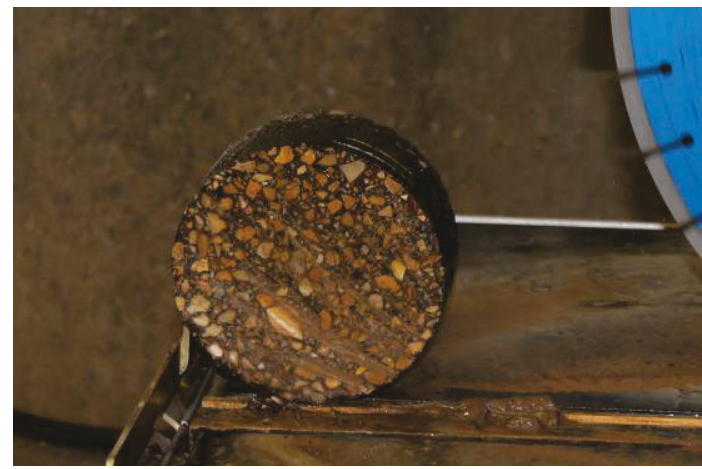

(b) Cut face after saw-cut.

Each selected treatment was applied to the cut face per the respective manufacturer's recommendations. Emulsion specimens (standard tack coat and Pavon) were prepared by applying a predetermined mass corresponding to targeted residual application rates $\left(0.05 \mathrm{gal} / \mathrm{yd}^{2}\right.$ for standard tack coat and $0.06 \mathrm{gal} / \mathrm{yd}^{2}$ for Pavon). Each product was uniformly distributed by hand and allowed to cure at ambient temperatures for a minimum of $48 \mathrm{hr}$ (Figure 4).

Figure 4. Emulsion application.

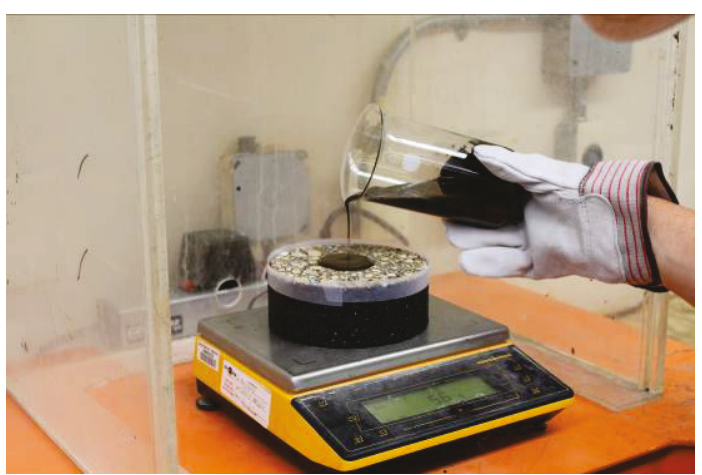

(a) Weighing emulsion.

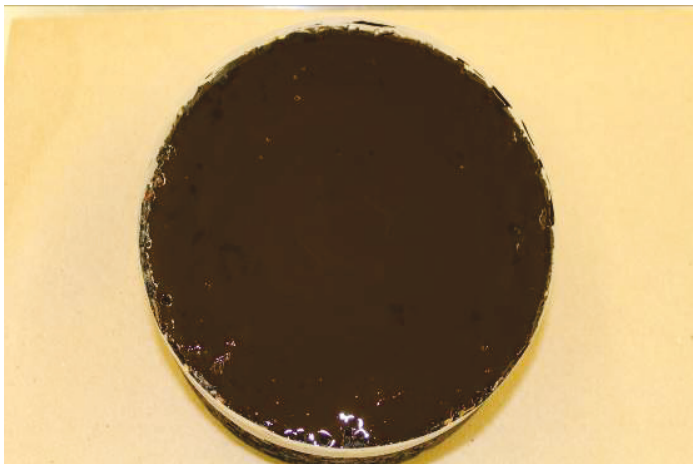

(c) Unbroken emulsion.

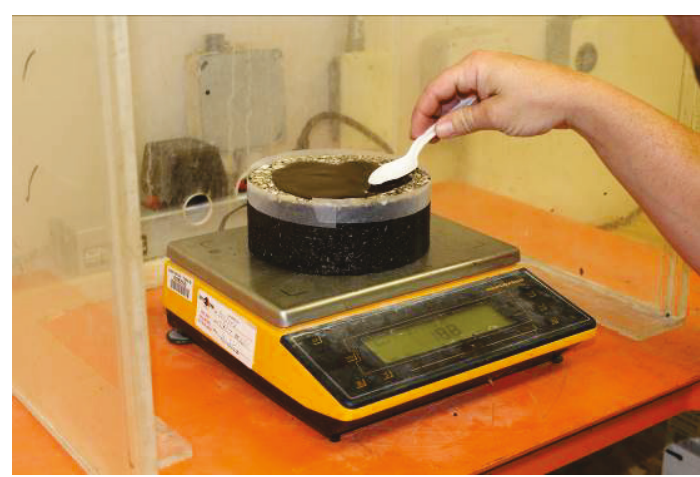

(b) Spreading emulsion.

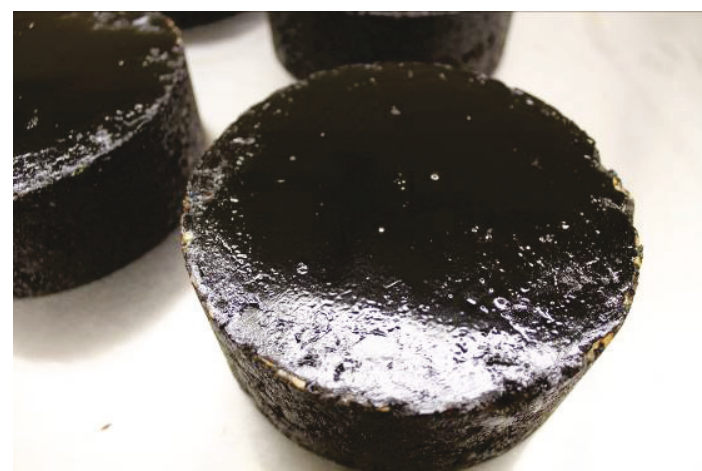

(d) Completed application. 
Rubberized joint adhesive was applied, as shown in Figure 5 .

Manufacturer's installation instructions recommended that the product be applied 1/8-in. thick, so a metal plate template slightly smaller than the top of the gyratory specimen was fabricated. Material was heated to $380^{\circ} \mathrm{F}$ so that it could be poured on the specimen and struck off using a heated metal straight edge. Figure 5 d shows a completed specimen.

Figure 5. Joint adhesive preparation.

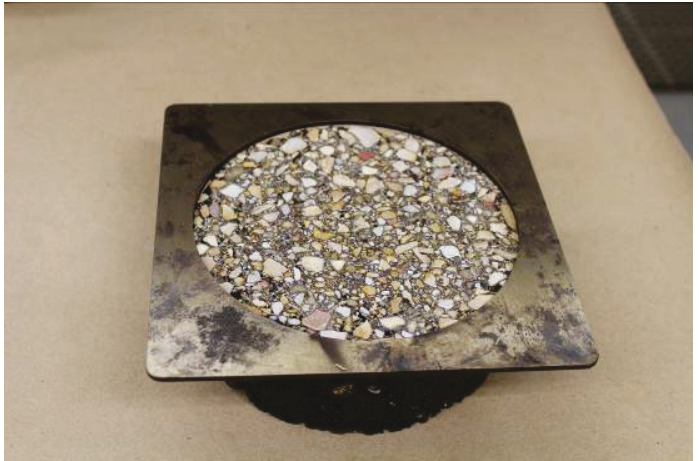

(a) Strike-off template on specimen.

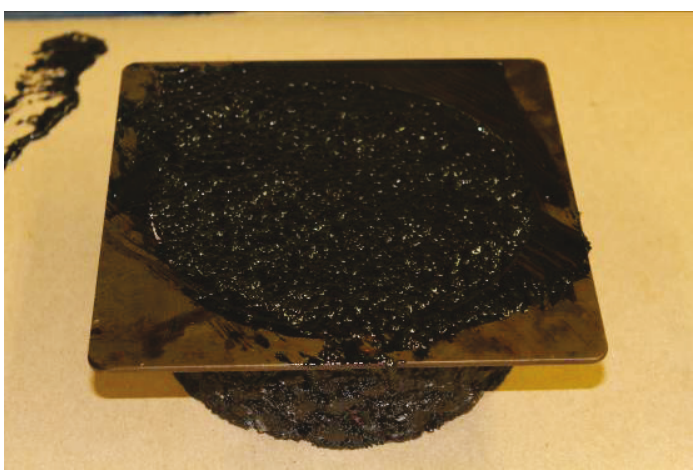

(c) Completed strike-off.

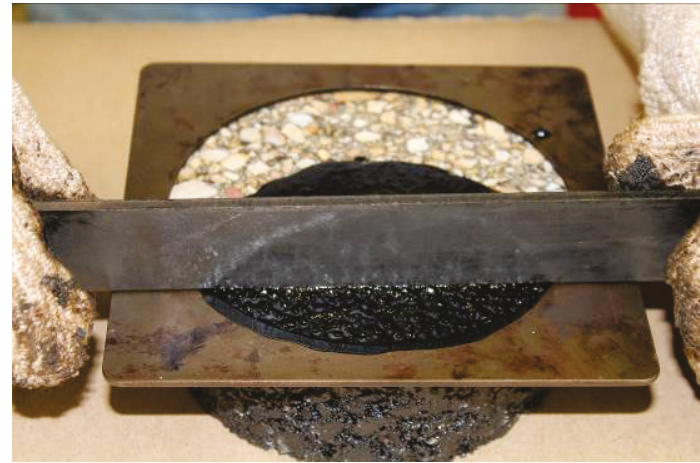

(b) Striking off heated material.

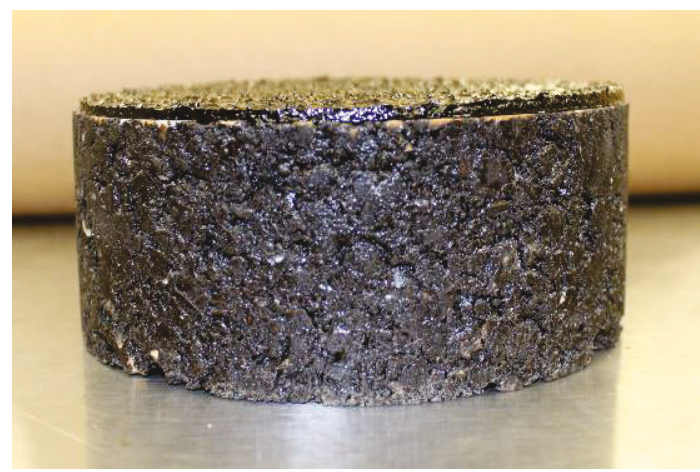

(d) Cooled and completed specimen.

Prepared specimens were placed in the bottom of a gyratory compactor mold with the treated face up. Hot mix asphalt was placed in the mold, and the specimen was compacted to 85 gyrations using the Superpave gyratory compactor, simulating the hot/cold joint interface commonly observed during field construction and providing a repeatable compactive effort. After compaction, the specimens were extruded from the Superpave gyratory mold and allowed to cool to ambient temperature.

Beam specimens were saw-cut from the composite Superpave gyratory specimens to perform maximum tensile strength tests in general accordance with ASTM D5329, Standard Test Methods for Sealants and 
Fillers, Hot-Applied, for Joints and Cracks in Asphalt Pavements and Portland Cement Pavements (2016). Two beam specimens were obtained from one gyratory specimen. Three specimens were tested to determine average tensile strength values, and the fourth specimen was retained for additional testing, if required. A schematic showing the typical saw-cut pattern for beam specimen fabrication is seen in Figure 6. Specimen preparation is shown in Figure 7.

Figure 6. Schematic of typical saw-cut pattern.

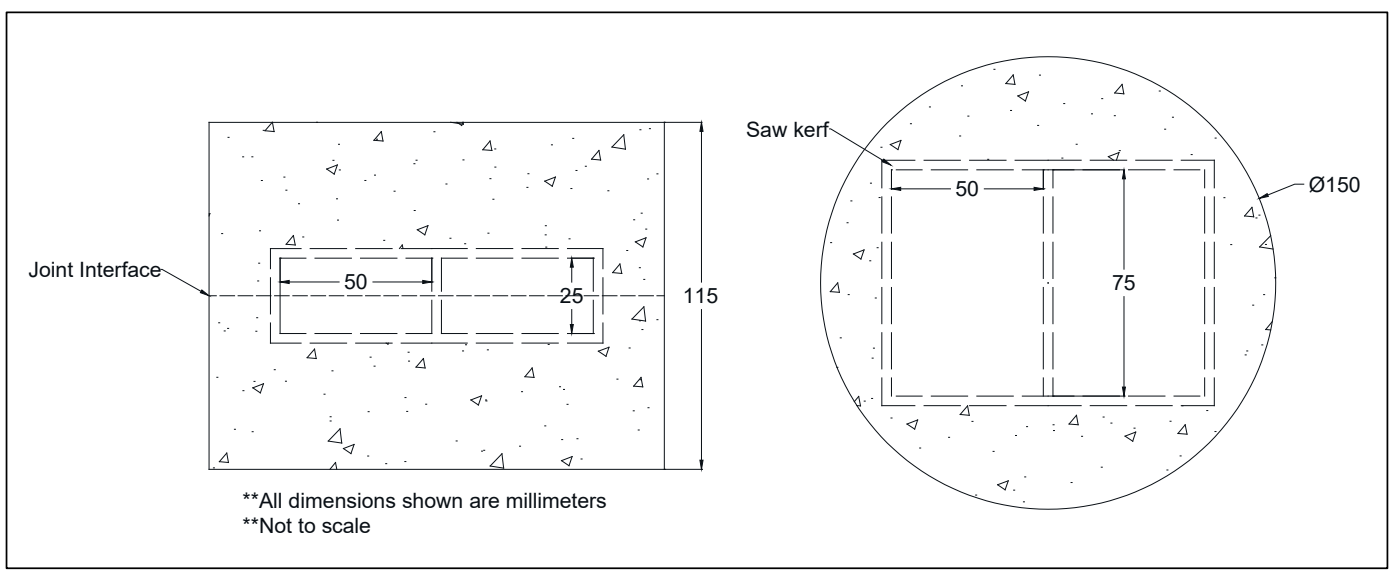

Figure 7. Beam specimen preparation.

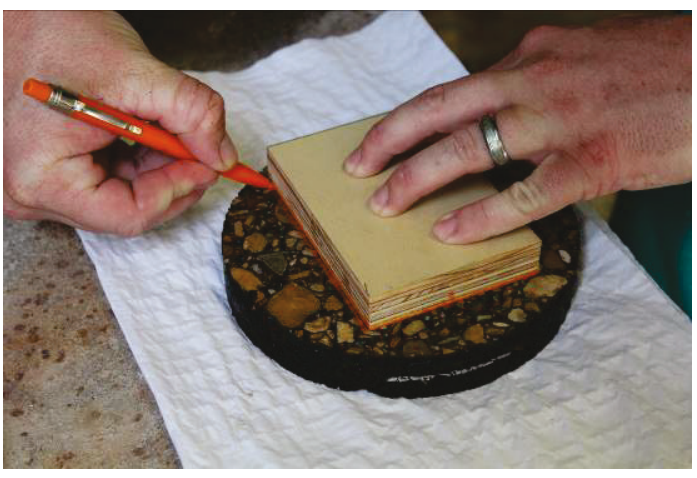

(a) Marking beam outline.

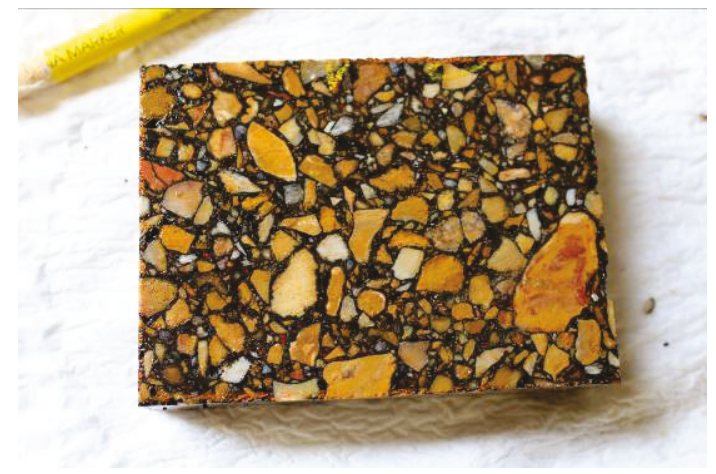

(c) Plan view.

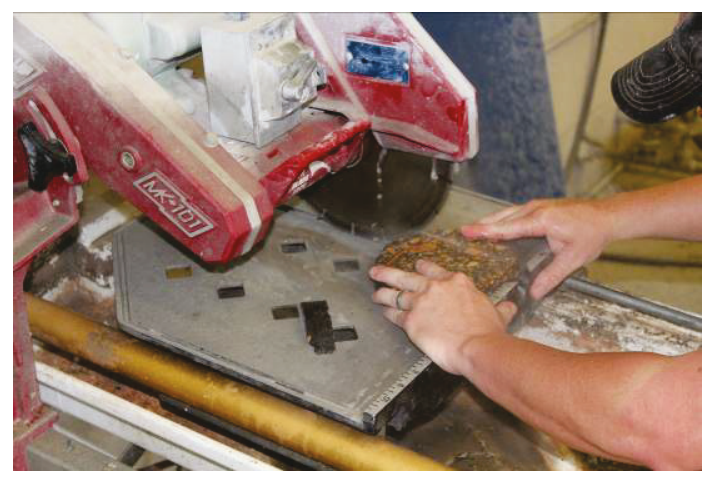

(b) Saw-cutting beam specimen.

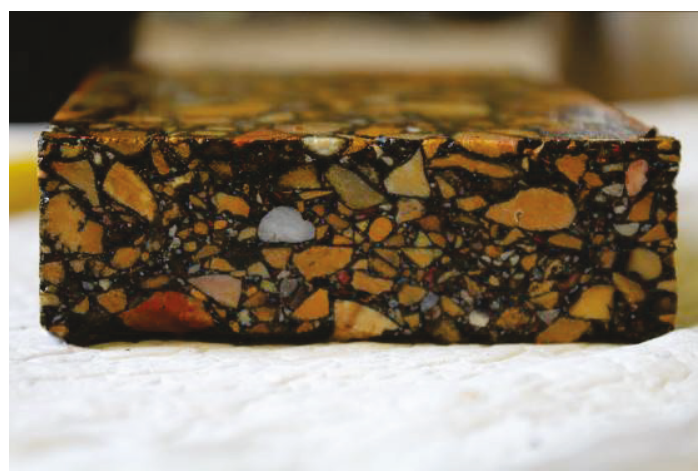

(d) Profile view. 
After saw-cutting was complete, specimens were adhered to steel plates (Figure 8) by using a flexible, two-part epoxy system that had an operational rating of $-50^{\circ} \mathrm{F}$ to $350^{\circ} \mathrm{F}$. The surface of each steel plate was roughened and a series of through-holes were drilled in each plate to promote adhesion.

Figure 8. Specimen adhered to steel plate.

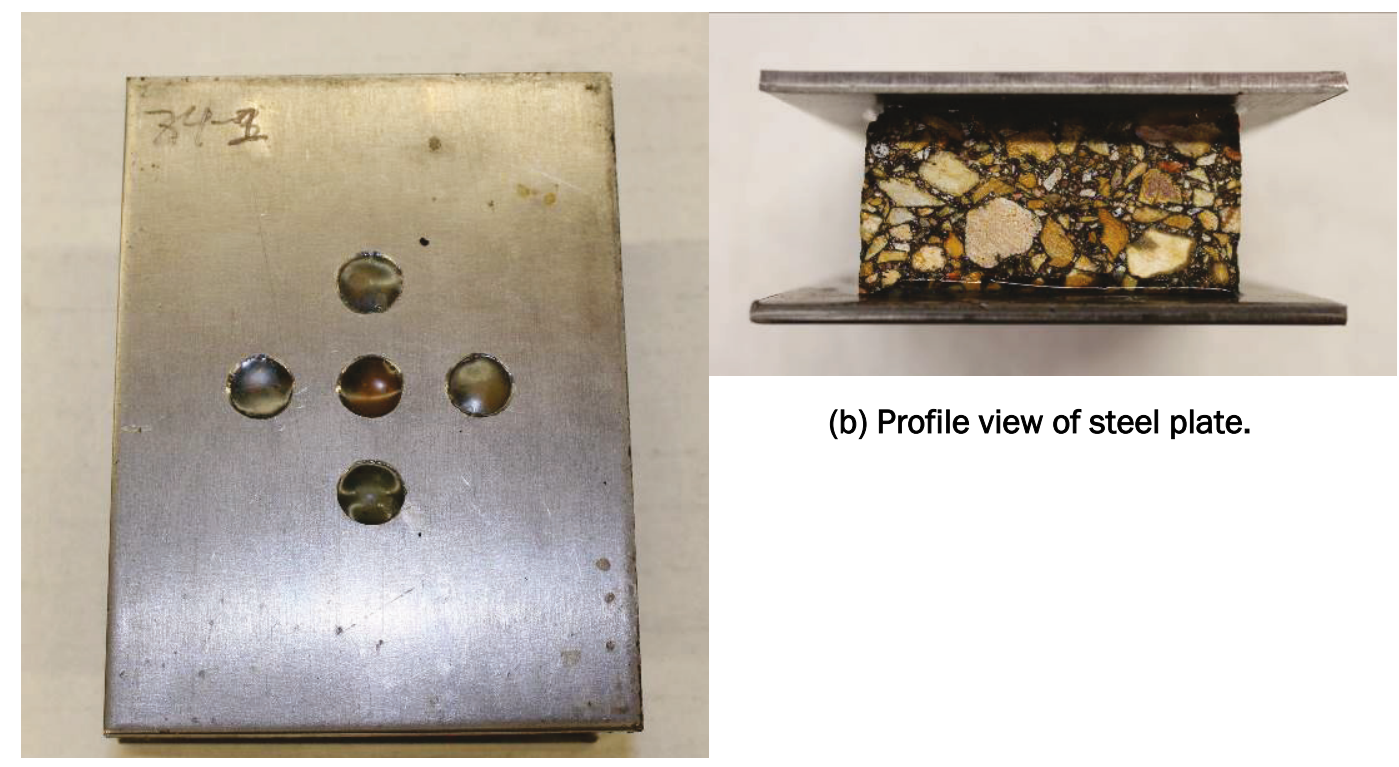

(a) Plan view of steel plate.

\subsection{Tensile test equipment}

Specimens were placed in an Applied Test Systems (ATS) testing frame for direct tensile strength determination. The ATS system consisted of a computer-controlled load frame that was modified to measure load and elongation over the testing sequence. An integrated environmental chamber was capable of maintaining the required test temperature over the duration of the test. Liquid nitrogen was used to maintain subfreezing test temperatures. The ATS test system is shown in Figure 9. 
Figure 9. ATS load frame and environmental chamber.

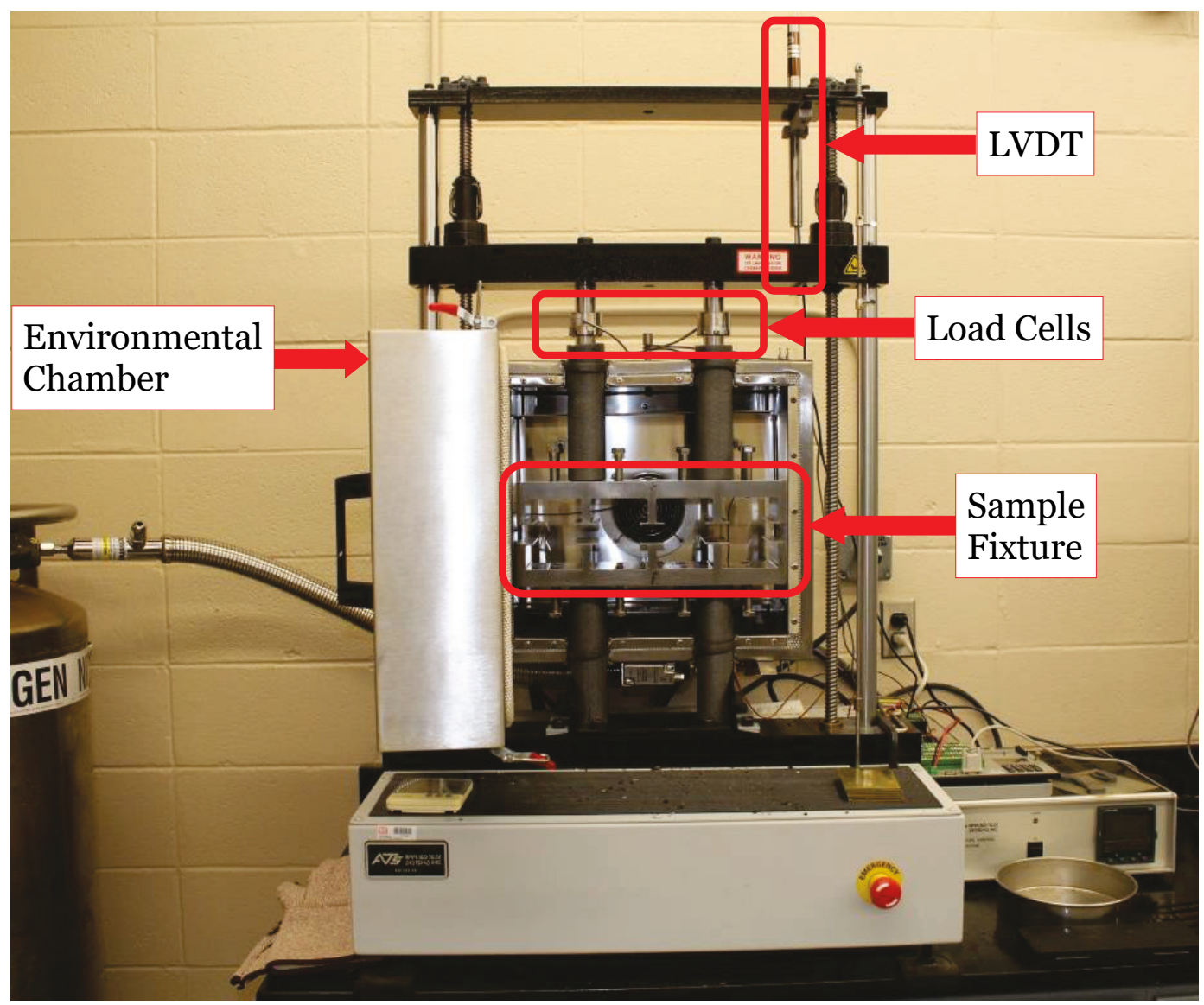

A low temperature sweep was performed to assemble strength data over a range of climatic conditions. Specimens were tested until failure, and the mode of failure (joint failure at the interface or tensile failure of the asphalt mixture) was noted. The test matrix for this study is presented in Table 2.

Table 2. Laboratory test temperature matrix.

\begin{tabular}{|l|l|l|l|l|l|}
\hline \multirow{2}{*}{ Joint Treatment } & \multicolumn{3}{l|}{ Test Temperature $\left({ }^{\circ} \mathrm{F}\right)$} & \multirow{2}{*}{ Total Specimens } \\
\cline { 2 - 6 } & -30 & 0 & 30 & 60 & \\
\hline No Treatment & 3 & 3 & 3 & 3 & 12 \\
\hline Tack Coat (Emulsion) & 3 & 3 & 3 & 3 & 12 \\
\hline PAVON & 3 & 3 & 3 & 3 & 12 \\
\hline CRAFCO $^{\circledR}$ No. 34524 & 3 & 3 & 3 & 3 & 12 \\
\hline No Joint & 3 & 3 & 3 & 3 & 12 \\
\hline
\end{tabular}


Specimens were pre-conditioned in a laboratory freezer or refrigerator to ensure that the target temperature was achieved. A dummy specimen was instrumented with an internal thermocouple and placed in the freezer at the same time as the test specimens. The instrumented specimen was monitored, and test specimens were placed in the ATS chamber after the dummy specimen reached test temperature. A load rate was applied (.0021 in./min, $0.125 \mathrm{in} . / \mathrm{hr}$ ) to simulate loading applied during temperature cycling. 


\section{Results and Discussion}

\subsection{Data summary}

Raw laboratory test data are located in Appendix A. Tensile test data are summarized in Figures 10 through 13 for each test temperature. Average ultimate load is presented for each treatment type as vertical bars on the primary y-axis. Elongation is presented as circles on the secondary y-axis and was selected based on elongation at ultimate load.

It was observed that specimens treated with standard tack coat had the highest tensile loads for all test temperatures with the exception of $-30^{\circ} \mathrm{F}$. Tensile strengths in joint adhesive products generally increased as temperature decreased, and specimens with no treatment or standard tack were found to decrease or remain relatively constant as temperature decreased. Specimens treated with joint adhesive products sustained lower tensile loads when compared to specimens with no treatment or standard tack coat.

Figure 10. Ultimate load and elongation at $60^{\circ} \mathrm{F}$.

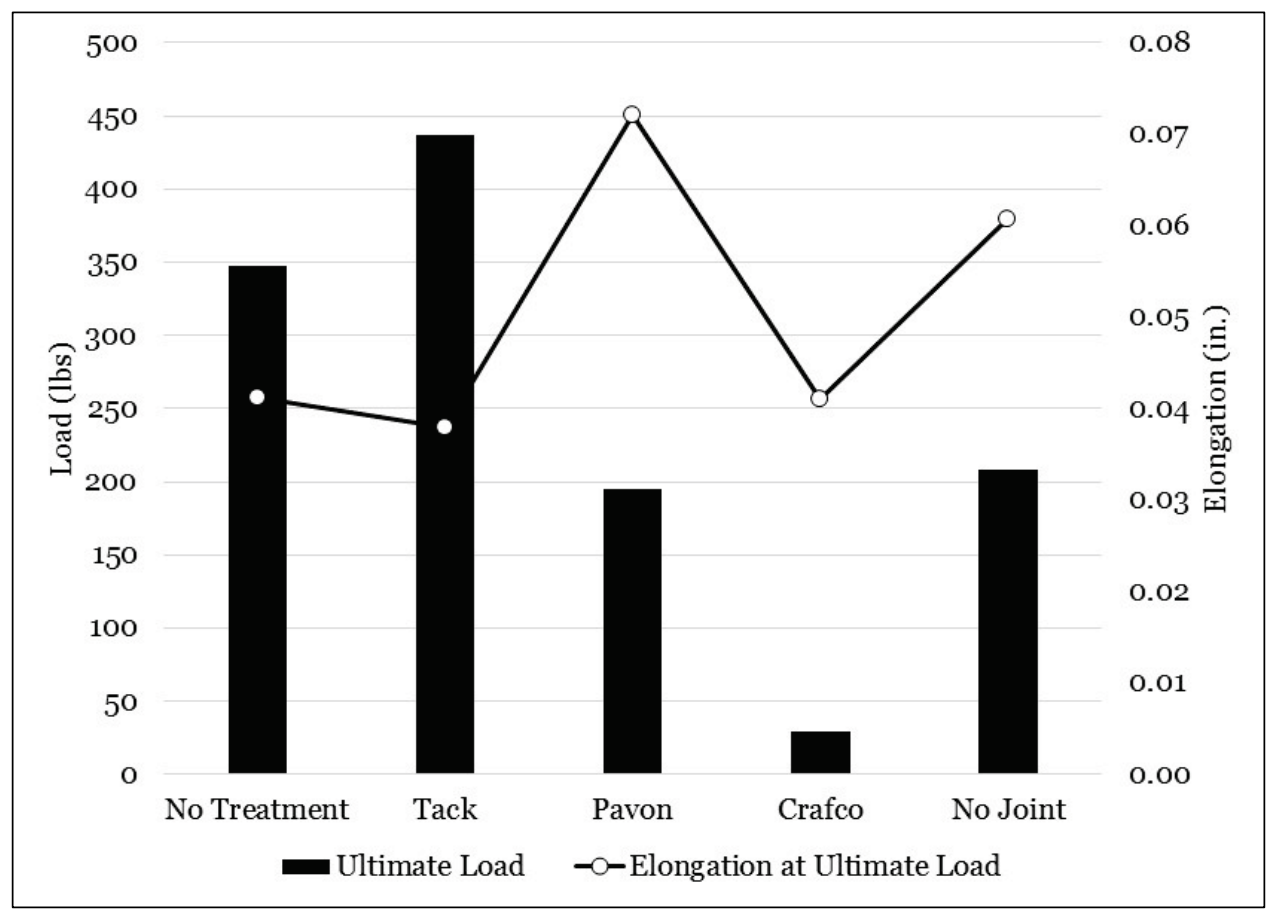


Figure 11. Load and elongation at $30^{\circ} \mathrm{F}$.

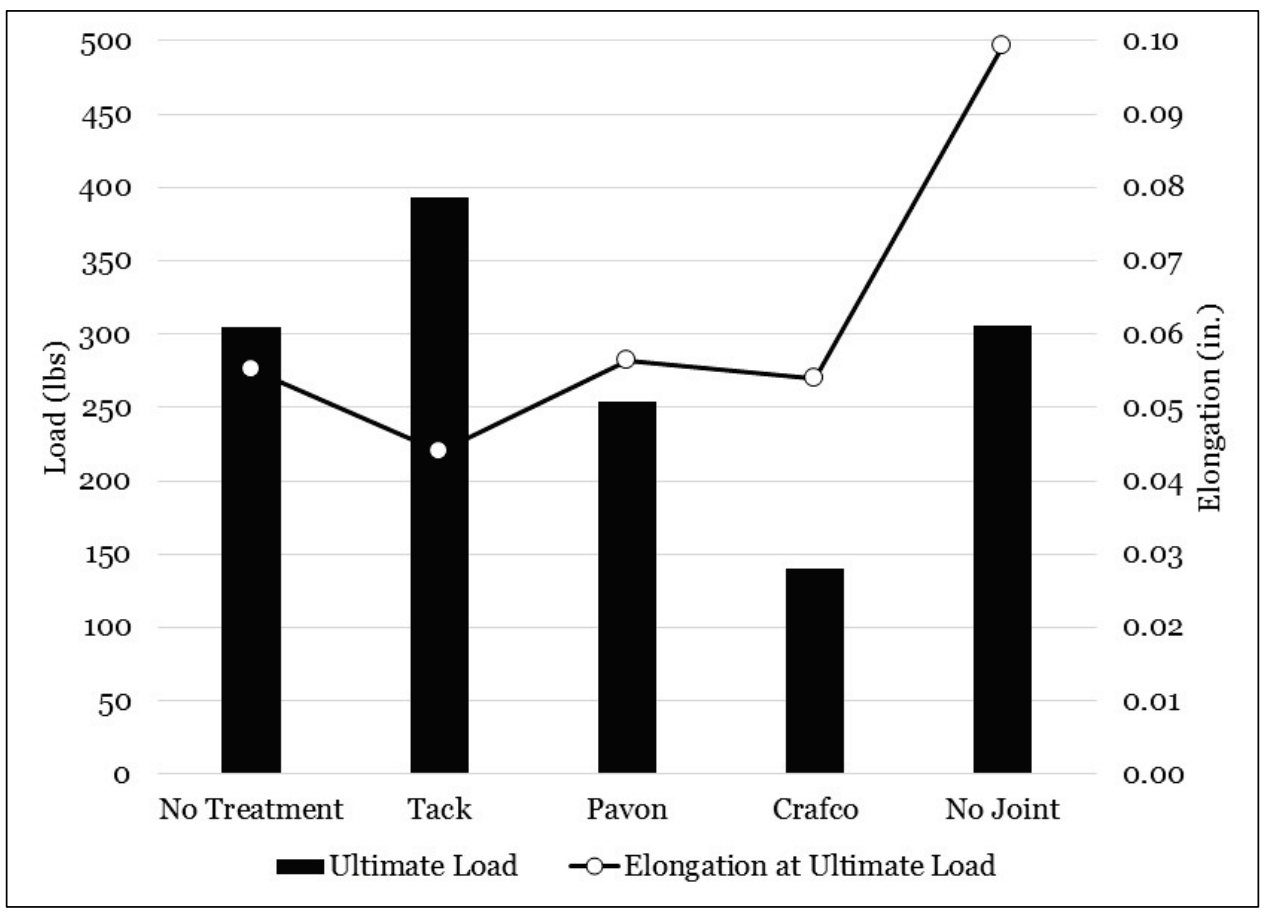

Figure 12. Load and elongation at $0^{\circ} \mathrm{F}$.

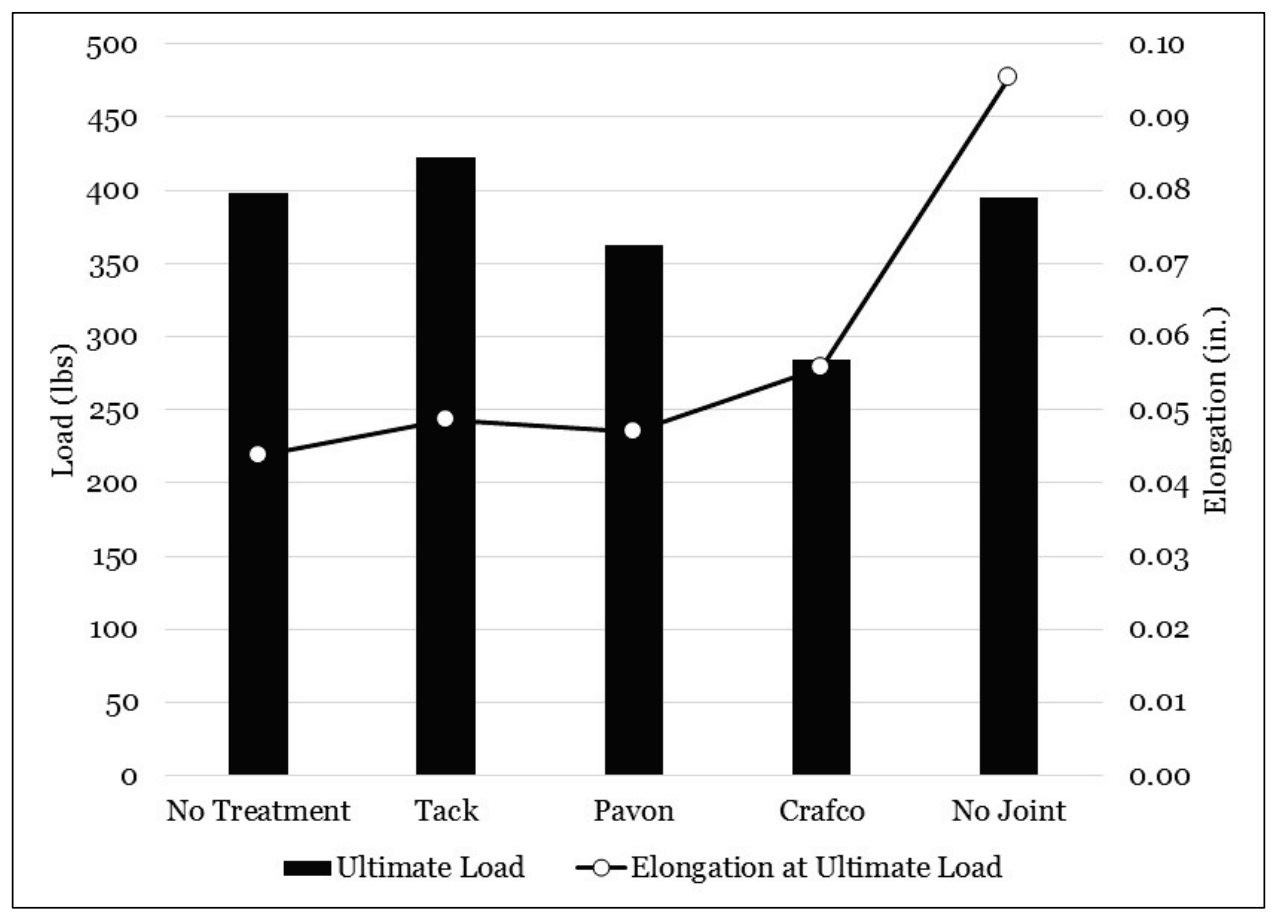


Figure 13. Load and elongation at $-30^{\circ} \mathrm{F}$.

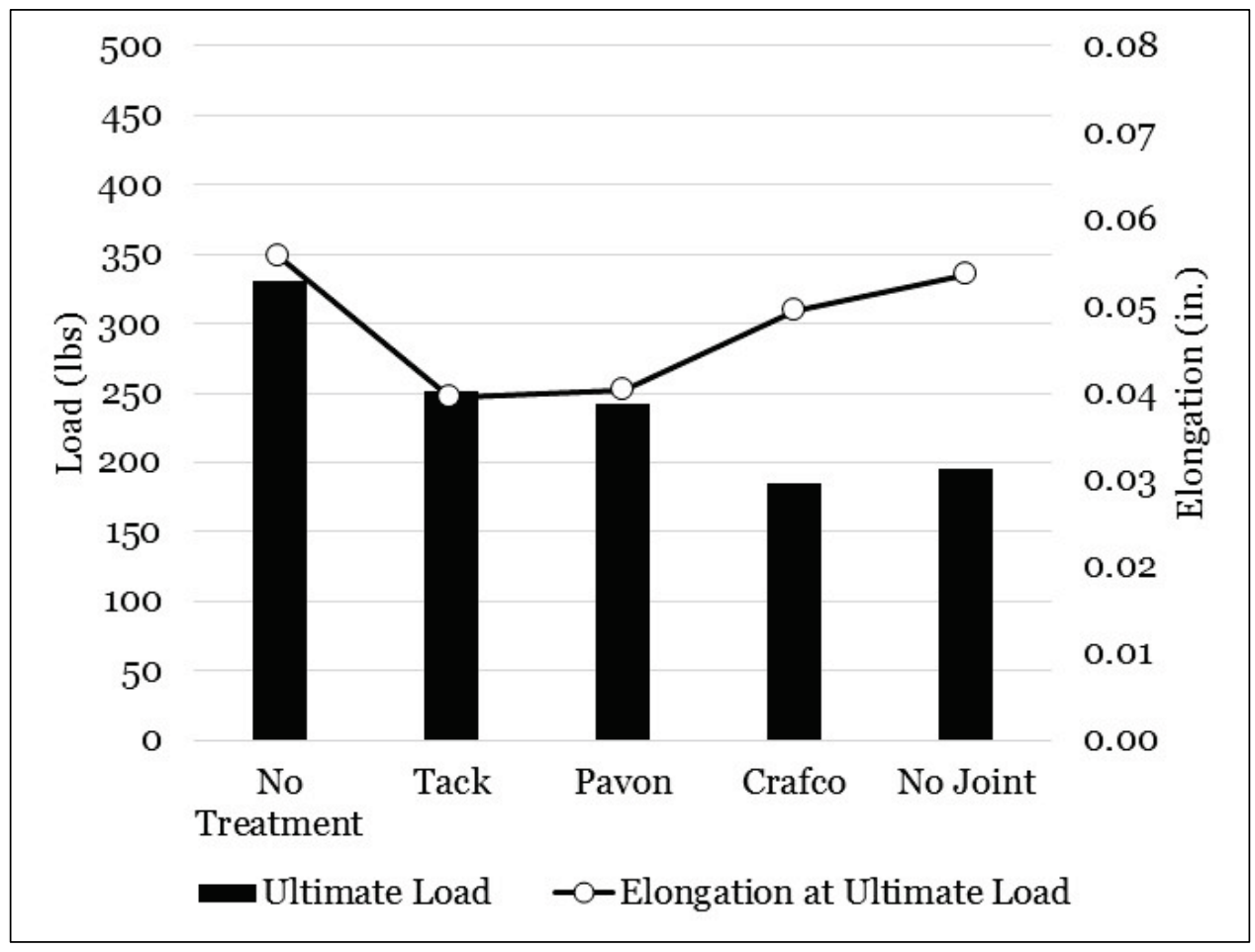

\subsection{Statistical analysis}

A statistical analysis of variance (ANOVA) of the data was performed. The experimental factors were test temperature (four levels) and treatment (five levels). The response variables were ultimate load and ultimate elongation. A generalized linear model was fitted to the response data. For the response of ultimate elongation, a summary of the statistical analysis is present in Table 3 . The adjusted $\mathrm{R}^{2}$ for the model is $28 \%$. The interaction term is not significant. The factor of temperature was found to be not statistically significant, while the treatment factor was found to be statistically significant at the 95\% confidence level.

Table 3. Statistical summary for ultimate elongation (all treatments).

\begin{tabular}{|l|l|l|l|l|l|}
\hline Source & df & Adj. SS & Adj. MS & F-value & P-value \\
\hline Temperature & 3 & 0.0019 & .0006 & 1.84 & 0.152 \\
\hline Treatment & 4 & 0.0085 & .0021 & 6.23 & 0.000 \\
\hline Temp. * Treat. & 12 & 0.0058 & .0004 & 1.63 & 0.121 \\
\hline Error & 40 & 0.0120 & .0003 & & \\
\hline Total & 59 & 0.0282 & & & \\
\hline
\end{tabular}


Multiple pairwise comparison procedures at the 95\% confidence level (Tukey method and Fisher least significant difference [LSD] method) were used to assess the statistical differences in each treatment. Results are provided in Table 4. Means that do not share a letter are significantly different. It is observed that specimens with no joint are significantly different from the remaining treatments.

Table 4. Multiple pairwise comparison for ultimate elongation (all treatments).

\begin{tabular}{|l|l|l|l|l|l|l|}
\hline Treatment & N & Mean & \multicolumn{2}{|l|}{ Tukey } & \multicolumn{2}{l|}{ Fisher LSD } \\
\hline No Joint & 12 & 0.0772 & A & & A & \\
\hline Pavon & 12 & 0.0539 & & B & & B \\
\hline Crafco $^{\circledR}$ & 12 & 0.0499 & & B & & B \\
\hline No Tack & 12 & 0.0489 & & B & & B \\
\hline Tack & 12 & 0.0425 & & B & & B \\
\hline
\end{tabular}

For the response of ultimate load, a summary of the ANOVA is presented in Table 5. The adjusted $\mathrm{R}^{2}$ for the model is $45 \%$, and it was found that the factors of temperature and treatment were statistically significant. The interaction term was not significant.

Table 5. Statistical summary for ultimate load (all treatments).

\begin{tabular}{|c|l|l|l|l|l|}
\hline Source & df & Adj. SS & Adj. MS & F-value & P-value \\
\hline Temperature & 3 & 170,232 & 56,744 & 6.10 & 0.000 \\
\hline Treatment & 4 & 337,357 & 84,339 & 9.07 & 0.001 \\
\hline Temp. * Treat. & 12 & 133,163 & 11,097 & 1.27 & 0.275 \\
\hline Error & 40 & 350,284 & 8,757 & & \\
\hline Total & 59 & 991,036 & & & \\
\hline
\end{tabular}

Pairwise comparisons for the factor of temperature are shown in Table 6. It was observed that specimens tested at $0^{\circ} \mathrm{F}$ were significantly different from the remaining test temperatures and that specimens tested at $30^{\circ} \mathrm{F}$ may or may not be significantly different, depending on the analysis method.

Table 6. Multiple pairwise comparison for test temperature (all treatments).

\begin{tabular}{|l|l|l|l|l|l|l|}
\hline Temperature & N & Mean & \multicolumn{2}{|l|}{ Tukey } & \multicolumn{2}{l|}{ Fisher LSD } \\
\hline $0^{\circ} \mathrm{F}$ & 15 & 372 & A & & A & \\
\hline $30^{\circ} \mathrm{F}$ & 15 & 280 & A & B & & B \\
\hline $60^{\circ} \mathrm{F}$ & 15 & 243 & & B & & B \\
\hline$-30^{\circ} \mathrm{F}$ & 15 & 241 & & B & & B \\
\hline
\end{tabular}


Pairwise comparisons for the factor of treatment are shown in Table 7. The general observation is that the tack and Crafco ${ }^{\circledR}$ treatments may be significantly different from the remaining treatments. No tack, no joint, and the Pavon product were not significantly different.

Table 7. Multiple pairwise comparison for treatment (all treatments).

\begin{tabular}{|l|l|l|l|l|l|l|l|}
\hline Treatment & N & Mean & \multicolumn{3}{|l|}{ Tukey } & \multicolumn{3}{l|}{ Fisher LSD } \\
\hline Tack & 12 & 376 & A & & A & & \\
\hline No Tack & 12 & 345 & A & & & B & \\
\hline No Joint & 12 & 276 & A & B & & B & \\
\hline Pavon & 12 & 263 & A & B & & B & \\
\hline Crafco $^{\circledR}$ & 12 & 160 & & B & & & C \\
\hline
\end{tabular}

In order to isolate the response of specimens containing a laboratory produced joint, test results from the no-joint specimens were removed from the dataset. Similarly, an ANOVA of the data was performed. The experimental factors were test temperature (four levels) and treatment (four levels). The response variables were ultimate load and ultimate elongation. A generalized linear model was fitted to the response data. For the response of ultimate elongation, none of the treatment factors were significant; no further statistical analysis was performed for these data. For the response of ultimate load, a summary of the statistical analysis is presented in Table 8 . The adjusted $\mathrm{R}^{2}$ for the model is $50 \%$. The interaction term is not significant. The factors of temperature and treatment are both significant at the $95 \%$ confidence level.

Table 8. Statistical ANOVA summary for ultimate load (jointed specimens only).

\begin{tabular}{|c|l|l|l|l|l|}
\hline Source & df & Adj. SS & Adj. MS & F-value & P-value \\
\hline Temperature & 3 & 107,748 & 35,916 & 3.92 & 0.017 \\
\hline Treatment & 3 & 336,425 & 111,142 & 12.23 & 0.000 \\
\hline Temp. * Treat. & 9 & 117,239 & 13,027 & 1.42 & 0.221 \\
\hline Error & 32 & 293,395 & 9,169 & & \\
\hline Total & 47 & 854,807 & & & \\
\hline
\end{tabular}

A main effects plot based on fitted means from the regression model is shown in Figure 14. The ultimate load increased with respect to decreasing temperature until the lowest temperature. As temperature decreased, it was observed that specimen failure transitioned from joint 
failure to failure through the asphalt mixture for all treatments, suggesting that adhesion at the joint becomes greater than the tensile strength of the parent asphalt at lower temperatures. Note that the asphalt binder grade used in this mixture has a low PG temperature of $-8^{\circ} \mathrm{F}\left(-22^{\circ} \mathrm{C}\right)$, so the lowest test temperature greatly exceeds the design temperature for this asphalt mixture. Below their respective PG low temperatures, asphalt binders become brittle and prone to thermal cracking.

Figure 14. Main effects plot for ultimate load.

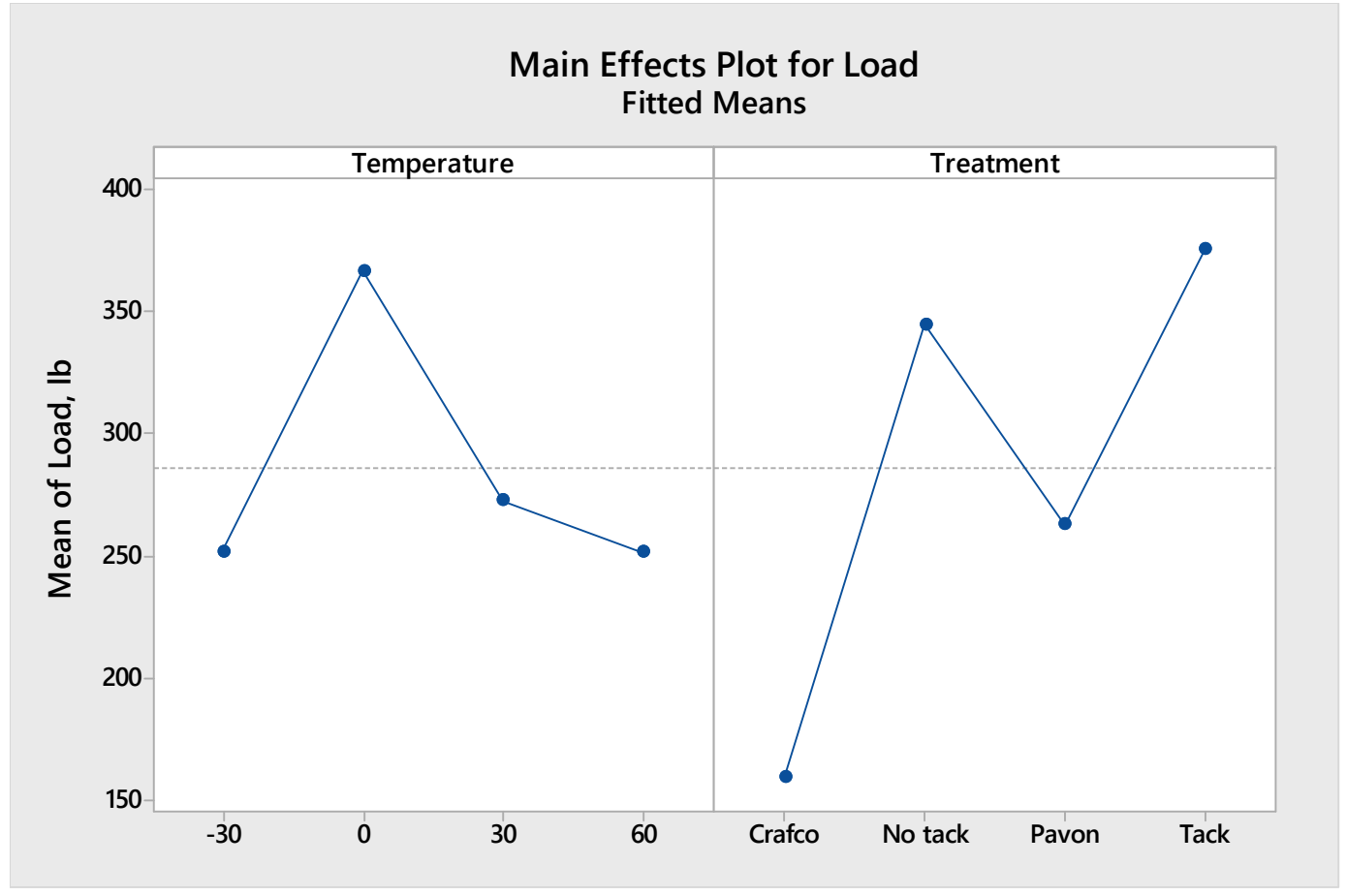

An interaction plot based on fitted means from the regression model is shown in Figure 15. The Crafco ${ }^{\circledR}$ product exhibits the lowest ultimate load of any of the treatments at all test temperatures, followed by the Pavon treatment. Tack and no-tack treatments have higher ultimate loads than the joint adhesive products at all test temperatures. At higher temperatures, the differences in ultimate load between treatment types is large. This coupled with the observation of joint failure modes for the higher temperature specimens indicates that differences in specimen treatment dominate the response. However, at lower temperatures, test results continued to show differences in specimen treatment, which was not expected. It is hypothesized that the heating process during compaction caused migration of the joint treatment products into the asphalt mixture, altering the effective asphalt proportions and asphalt strength properties. 
Figure 15. Interaction plot for ultimate load.

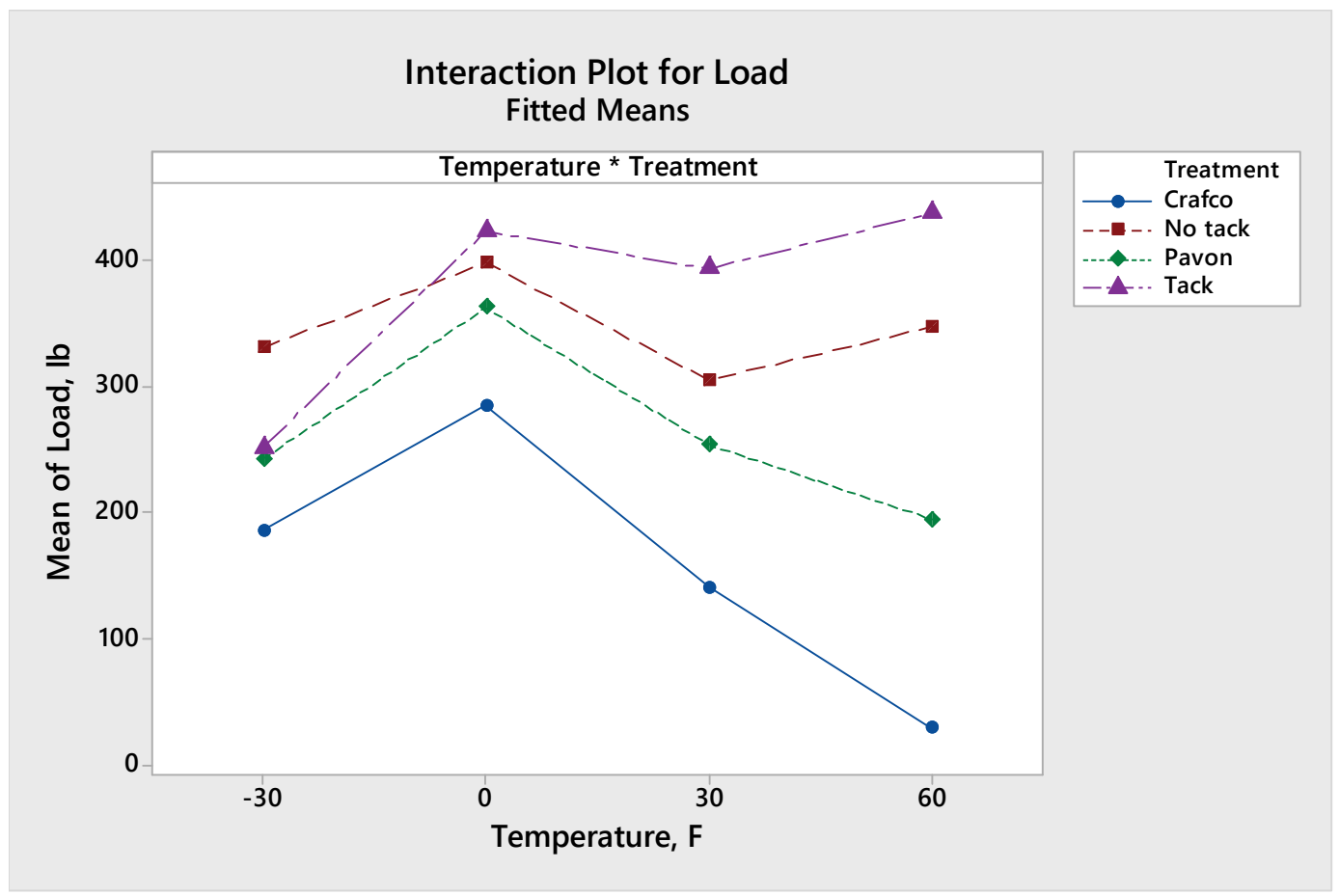

Multiple pairwise comparison procedures at the 95\% confidence level (Tukey method and Fisher least significant difference [LSD] method) were used to assess the statistical differences in each treatment. Results are provided in Table 9. Means that do not share a letter are significantly different. The general observation is that tack and no-tack treatments are not significantly different from each other. The Crafco ${ }^{\circledR}$ product is significantly different from both of them. The Pavon product is somewhere in between and may or may not be significantly different, depending on the analysis method.

Table 9. Multiple comparison procedure results (jointed specimens only).

\begin{tabular}{|l|l|l|l|l|l|l|l|l|}
\hline Treatment & N & Mean & \multicolumn{3}{|l|}{ Tukey } & \multicolumn{3}{|l|}{ Fisher LSD } \\
\hline Tack & 12 & 376 & A & & & A & & \\
\hline No Tack & 12 & 345 & A & B & & A & & \\
\hline Pavon & 12 & 263 & & B & C & & B & \\
\hline Crafco $^{\circledR}$ & 12 & 160 & & & C & & & C \\
\hline
\end{tabular}




\subsection{Discussion}

While the elongation data were too variable for statistical analysis, they can provide some insight into the relative performance of each treatment. In terms of elongation, joint adhesive specimens generally showed equal or higher elongation than no treatment and standard tack specimens. Visual inspection of joint adhesive specimens showed significant elongation during testing (Figure 16) with complete failure difficult to achieve. It is noted that joint adhesive post-test specimens could be re-adhered manually and were difficult to separate without significant manual force. This observation suggests that joint adhesive may display some "self-healing" properties if one considers the cyclic nature of joint movement.

Figure 16. Elongation during joint adhesive (Crafco $®)$ test.

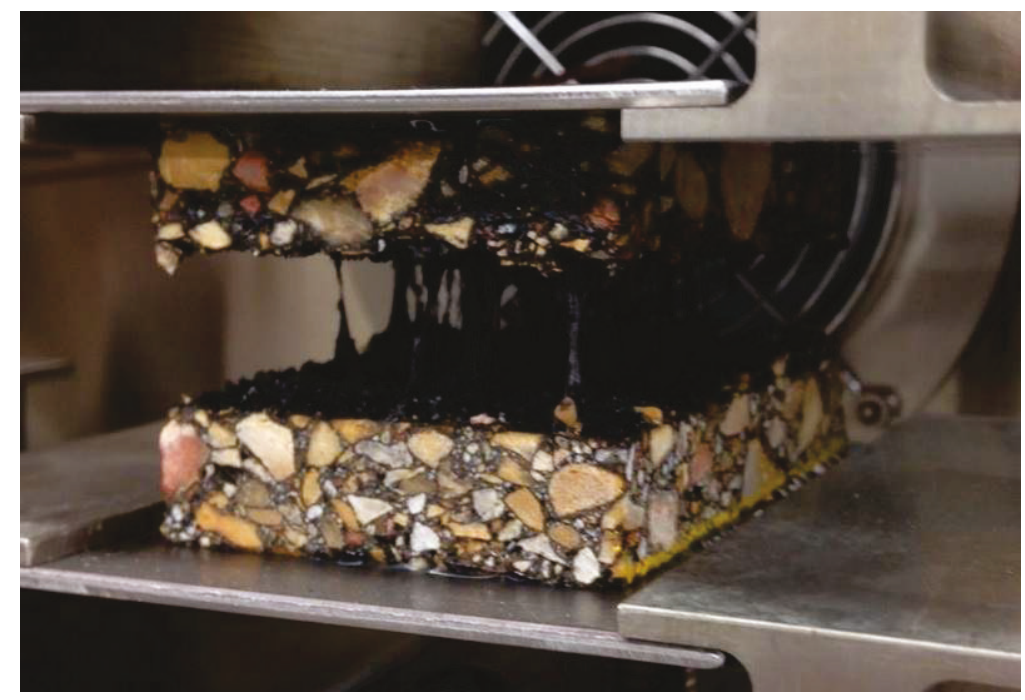

Typical load and elongation plots for each treatment are presented in Figure 17. It was observed that the joint adhesive products displayed significantly different load responses than the no-treatment and standard tack specimens. A lower slope was observed leading up to peak load, suggesting improved elastic properties.

When an asphalt pavement experiences a drop in temperature, each part of the pavement attempts to shrink while simultaneously being restrained by its neighbor; this induces internal stress to the asphalt mixture. At any weak plane in the pavement, such as a construction joint, cracking will occur if the internal stress exceeds the strength at that point. This relieves the built-up stress by releasing the energy as strain movement. 
The strain-rate-controlled testing in this study approaches the situation the opposite way. The load frame introduces a strain to the simulated pavement joint and measures the resulting stress that develops for a given amount of joint movement. Higher elongation at failure (and lower stress) is considered indicative of potentially better performance in the field where the amount of potential strain induced by temperature changes drives the joint behavior.

Figure 17. Typical load and elongation response at $60^{\circ} \mathrm{F}$.

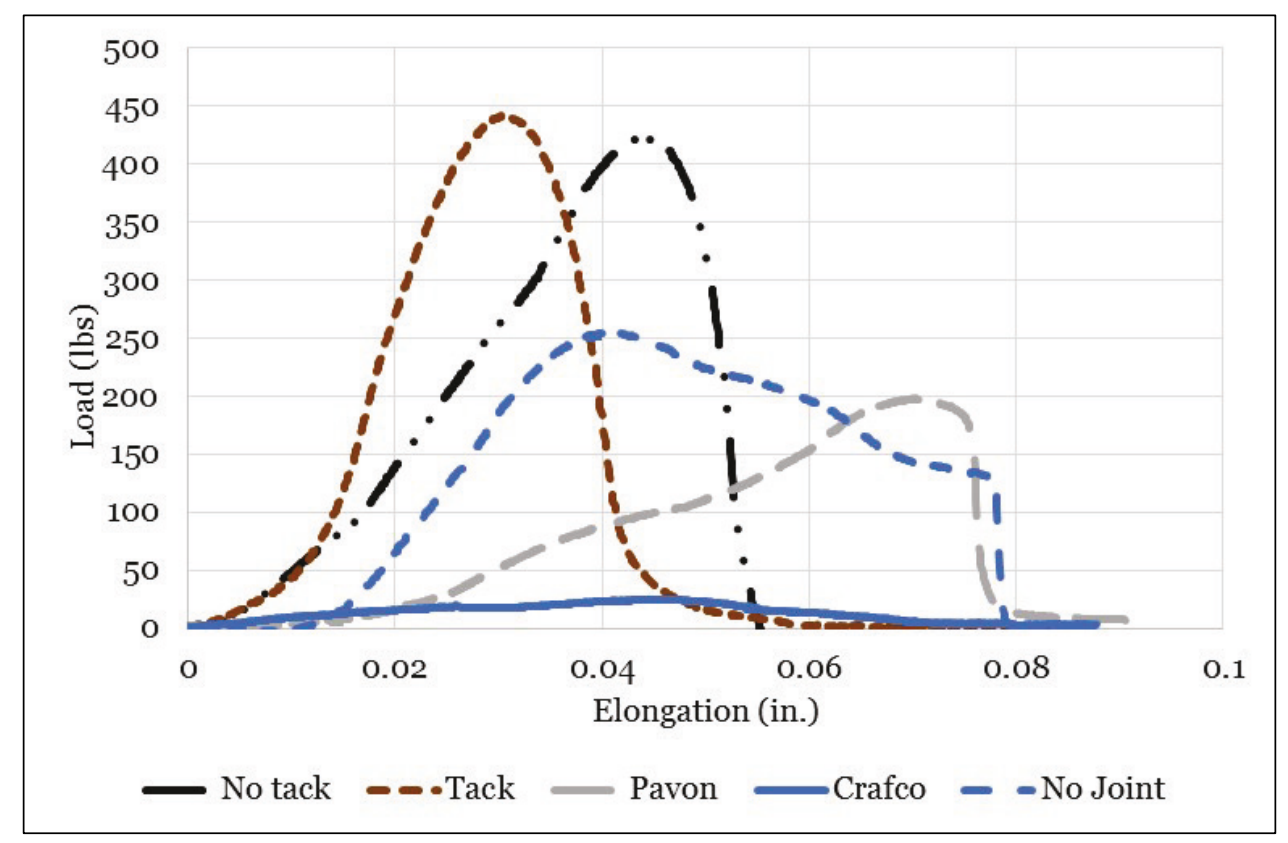




\section{Conclusions and Recommendations}

A literature review and limited laboratory study were conducted to investigate the performance of joint adhesive in asphalt pavement joint construction. The following conclusions are a result of this study.

- Current airfield specifications require cutting back the longitudinal construction joint and applying asphalt tack coat. Guidance regarding a proper application rate is not provided.

- The literature review indicates that little work has been performed for airfield pavements and that most field studies have been performed for highway pavements.

- Review of highway evaluations indicate that, based on visual inspection, joint adhesives have shown improvement in long-term performance.

- The laboratory results suggest that, based on observed elongation to failure, joint adhesives could provide an improvement in asphalt joint behavior.

- Laboratory tensile strength tests do not account for long-term aging from environmental exposure and may not be an indicator of long-term performance.

Based on the above conclusions, the following recommendations are made.

1. It is recommended that a field study be conducted to install and monitor airfield asphalt joints constructed with and without joint adhesive products.

2. Visual inspection should be performed over time to monitor the occurrence of longitudinal and transverse cracking to determine the longterm performance characteristics of joint adhesives.

3. It is recommended that a field study be conducted in an environment subjected to extreme temperature cycles to ensure maximum thermal expansion and contraction of the asphalt pavement. 


\section{References}

American Society of Testing Materials (ASTM). 2016. Standard test method for sealant and fillers, hot-applied, for joints and cracks in asphalt pavements and portland cement pavements. Designation D 5329-16. West Conshohocken, PA: American Society of Testing Materials.

Association of American Highway and Transportation Officials (AASHTO). 2012. Standard method of test theoretical maximum specific gravity $\left(G_{m m}\right)$ and density of hot mix asphalt (HMA). AASHTO T 209. Washington, DC: Association of American Highway and Transportation Officials.

. 2013. Standard method of test for bulk specific gravity $\left(G_{m b}\right)$ of compacted hot mix asphalt (HMA) using saturated surface-dry specimens. AASHTO T 166. Washington, DC: Association of American Highway and Transportation Officials.

Cooley Jr., L. A., E. R. Brown, and S. Maghsoodloo. 2001. Development of critical field permeability and pavement density values for coarse-graded Superpave pavements. Transportation Research Record: Journal of the Transportation Research Board 1761:41-49

Cooley Jr., L. A., B. D. Prowell, and E. R. Brown. 2002. Issues pertaining to the permeability characteristics of coarse-graded Superpave mixes. Asphalt Paving Technology 71:1-29.

Huang, B., X. Shu, J. Chen, and M. Woods. 2010. Evaluation of longitudinal joint construction techniques for asphalt pavements in Tennessee. Journal of Materials in Civil Engineering 22(11):1112-1121.

Kandhal, P., and R. B. Mallick. 1996. Study of longitudinal-joint construction techniques in hot-mix asphalt pavements. Transportation Research Record: Journal of the Transportation Research Board 1543:106-112.

Kandhal, P., T. Ramirez, and P. Ingram. 2002. Evaluation of eight longitudinal joint construction techniques for asphalt pavements in Pennsylvania. Transportation Research Record: Journal of the Transportation Research Board 1813:87-94.

Kandhal, P., and S. S. Rao. 1994. Evaluation of longitudinal joint construction techniques for asphalt pavements. Transportation Research Record: Journal of the Transportation Research Board 1469:18-25.

Linden, R. N., J. P. Mahoney, and N. C. Jackson. 1989. Effect of compaction on asphalt concrete performance. Transportation Research Record: Journal of the Transportation Research Board 1217:20-28.

Mallick, R. B., L. A. Cooley, Jr., M. R. Teto, R. L. Bradbury, and D. Peabody. 2003. An evaluation of factors affecting permeability of Superpave designed pavements. Report 03-02. Auburn, AL: National Center for Asphalt Technology.

Mallick, R. B., P. S. Kandhal, R. Ahlrich, and S. Parker. 2007. Improved performance of longitudinal joints on asphalt airfields. AAPTP Project: 04-05. Auburn, AL: Airfield Asphalt Pavement Technology Program. 
Morgan, R. L. 2009. Centerline (longitudinal) joint adhesive performance: two to threeyear review. Report FHWA/NY/SR-09/149. New York: State Department of Transportation.

U.S. Army Corps of Engineers. 2015. Hot-mix asphalt airfield paving. Unified Facilities Guide Specification 32-12-15.13. Washington, DC: U.S. Department of Defense.

U.S. Department of Transportation. 2014. Standards for specifying construction of airports. AC 150/5370-10. Washington, DC: Federal Aviation Administration.

Williams, S. G. 2011. HMA longitudinal joint evaluation and construction. TRC-0801 Final Report. Fayetteville, AR: University of Arkansas. 


\section{Appendix A: Laboratory Test Data}

\begin{tabular}{|c|c|c|c|c|}
\hline Temperature $\left({ }^{\circ} \mathrm{F}\right)$ & Treatment & $\begin{array}{l}\text { Ultimate Load } \\
\text { (Ib) }\end{array}$ & $\begin{array}{c}\text { Ultimate } \\
\text { Elongation (in.) }\end{array}$ & Failure Mode \\
\hline 60 & No tack & 425 & 0.0470 & Mixture \\
\hline 60 & No tack & 302 & 0.0365 & Joint \\
\hline 60 & No tack & 314 & 0.0401 & Joint \\
\hline 60 & Tack & 442 & 0.0306 & Joint \\
\hline 60 & Tack & 447 & 0.0385 & Joint \\
\hline 60 & Tack & 422 & 0.0446 & Joint \\
\hline 60 & Pavon & 198 & 0.0700 & Joint \\
\hline 60 & Pavon & 263 & 0.0527 & Joint \\
\hline 60 & Pavon & 123 & 0.0936 & Joint \\
\hline 60 & Crafco & 25 & 0.0457 & Joint \\
\hline 60 & Crafco & 39 & 0.0269 & Joint \\
\hline 60 & Crafco & 23 & 0.0503 & Joint \\
\hline 60 & No Joint & 107 & 0.0679 & Mixture \\
\hline 60 & No Joint & 256 & 0.0405 & Mixture \\
\hline 60 & No Joint & 263 & 0.0735 & Mixture \\
\hline 30 & No tack & 485 & 0.0552 & Mixture \\
\hline 30 & No tack & 307 & 0.0716 & Joint \\
\hline 30 & No tack & 122 & 0.0388 & Joint \\
\hline 30 & Tack & 235 & 0.0518 & Mixture \\
\hline 30 & Tack & 462 & 0.0408 & Mixture \\
\hline 30 & Tack & 482 & 0.0390 & Mixture \\
\hline 30 & Pavon & 158 & 0.0416 & Mixture \\
\hline 30 & Pavon & 335 & 0.0562 & Mixture \\
\hline 30 & Pavon & 268 & 0.0712 & Mixture \\
\hline 30 & Crafco & 105 & 0.0755 & Joint \\
\hline 30 & Crafco & 192 & 0.0355 & Joint \\
\hline 30 & Crafco & 124 & 0.0506 & Joint \\
\hline 30 & No Joint & 361 & 0.0774 & Mixture \\
\hline 30 & No Joint & 154 & 0.0811 & Mixture \\
\hline 30 & No Joint & 402 & 0.1394 & Mixture \\
\hline 0 & No tack & 560 & 0.0261 & Mixture \\
\hline
\end{tabular}




\begin{tabular}{|c|c|c|c|c|}
\hline Temperature $\left({ }^{\circ} \mathrm{F}\right)$ & Treatment & $\begin{array}{l}\text { Ultimate Load } \\
\text { (Ib) }\end{array}$ & $\begin{array}{c}\text { Ultimate } \\
\text { Elongation (in.) }\end{array}$ & Failure Mode \\
\hline 0 & No tack & 238 & 0.0286 & Mixture \\
\hline 0 & No tack & 395 & 0.0765 & Mixture \\
\hline 0 & Tack & 261 & 0.0431 & Mixture \\
\hline 0 & Tack & 491 & 0.0462 & Mixture \\
\hline 0 & Tack & 516 & 0.0566 & Mixture \\
\hline 0 & Pavon & 391 & 0.0422 & Mixture \\
\hline 0 & Pavon & 317 & 0.0605 & Mixture \\
\hline 0 & Pavon & 378 & 0.0383 & Mixture \\
\hline 0 & Crafco & 208 & 0.0707 & Mixture \\
\hline 0 & Crafco & 352 & 0.0493 & Mixture \\
\hline 0 & Crafco & 293 & 0.0468 & Mixture \\
\hline 0 & No Joint & 446 & 0.1034 & Mixture \\
\hline 0 & No Joint & 349 & 0.1119 & Mixture \\
\hline 0 & No Joint & 390 & 0.0705 & Mixture \\
\hline-30 & No tack & 385 & 0.0488 & Joint \\
\hline-30 & No tack & 361 & 0.0546 & Mixture \\
\hline-30 & No tack & 245 & 0.0639 & Mixture \\
\hline-30 & Tack & 249 & 0.0367 & Mixture \\
\hline-30 & Tack & 339 & 0.0333 & Mixture \\
\hline-30 & Tack & 166 & 0.0483 & Mixture \\
\hline-30 & Pavon & 149 & 0.0151 & Mixture \\
\hline-30 & Pavon & 238 & 0.0522 & Mixture \\
\hline-30 & Pavon & 339 & 0.0538 & Mixture \\
\hline-30 & Crafco & 166 & 0.0626 & Mixture \\
\hline-30 & Crafco & 209 & 0.0329 & Mixture \\
\hline-30 & Crafco & 181 & 0.0529 & Mixture \\
\hline-30 & No Joint & 172 & 0.0764 & Mixture \\
\hline-30 & No Joint & 222 & 0.0414 & Mixture \\
\hline-30 & No Joint & 191 & 0.0431 & Mixture \\
\hline
\end{tabular}




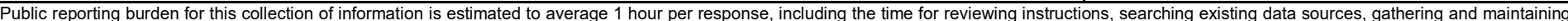

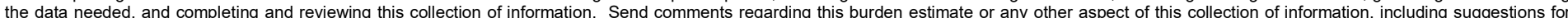

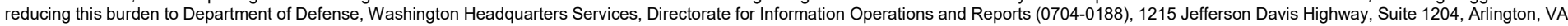

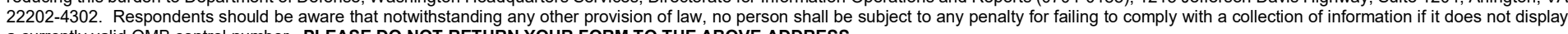
a currently valid OMB control number. PLEASE DO NOT RETURN YOUR FORM TO THE ABOVE ADDRESS.
1. REPORT DATE (DD-MM-YYYY)
April 2019

\section{TITLE AND SUBTITLE}

Laboratory Tensile Performance of Joint Adhesive for Asphalt Pavements
3. DATES COVERED (From - To)

\section{5a. CONTRACT NUMBER}

5b. GRANT NUMBER

5c. PROGRAM ELEMENT NUMBER

5d. PROJECT NUMBER

5e. TASK NUMBER

5f. WORK UNIT NUMBER

464296

\section{PERFORMING ORGANIZATION NAME(S) AND ADDRESS(ES)}

8. PERFORMING ORGANIZATION REPORT NUMBER

ERDC/GSL TR-19-13

Geotechnical and Structures Laboratory

U.S. Army Engineer Research and Development Center

3909 Halls Ferry Road

Vicksburg, MS 39180-6199

\section{SPONSORING / MONITORING AGENCY NAME(S) AND ADDRESS(ES)}

U.S. Army Installation Management Command

2405 Gun Shed Road

Fort Sam Houston, TX 78234-1223

11. SPONSOR/MONITOR'S REPORT NUMBER(S)

\section{DISTRIBUTION / AVAILABILITY STATEMENT}

Approved for public release; distribution is unlimited.

\section{SUPPLEMENTARY NOTES}

\section{ABSTRACT}

Deterioration of asphalt pavement joints is one of the most commonly observed distresses on Army airfield pavements. Joint opening or cracking is typically caused by temperature cycling and associated thermal expansion of the asphalt pavements and is often seen around the perimeter of hot mix asphalt patching and along longitudinal paving joints. An improvement in joint performance has the potential for significant maintenance cost savings to the Army. The objective of this effort was to perform a literature review of current specifications and available field evaluation studies and to conduct laboratory testing of currently available joint adhesive products to observe tensile strength and elongation characteristics at a variety of test temperatures. Review of limited highway evaluations indicate that, based on visual inspection, joint adhesives have shown improvement in long-term performance; and laboratory results suggest that, based on observed elongation, joint adhesives can provide an improvement in asphalt joint behavior.

\begin{tabular}{|ll}
\hline 15. SUBJECT TERMS & Joint adhesive \\
Airfield & Cracking \\
Pavement & Runways (Aeronautics) - Maintenance and repair \\
\hline 16. SECURTY &
\end{tabular}

16. SECURITY CLASSIFICATION OF:

\begin{tabular}{|l|l|}
\hline a. REPORT & $\begin{array}{l}\text { b. ABSTRACT } \\
\text { Unclassified }\end{array}$ \\
Unclassified
\end{tabular}

17. LIMITATION OF ABSTRACT

\author{
Pavements, Asphalt - Joints \\ Concrete construction - Joints
}

\begin{tabular}{c|l}
$\begin{array}{l}\text { 18. NUMBER } \\
\text { OF PAGES }\end{array}$ & $\begin{array}{l}\text { 19a. NAME OF RESPONSIBLE } \\
\text { PERSON }\end{array}$ \\
\cline { 2 - 2 } 40 & $\begin{array}{l}\text { 19b. TELEPHONE NUMBER (include } \\
\text { area code) }\end{array}$ \\
\hline
\end{tabular}

